\title{
Article \\ Comparative Analysis of Energy and GHG Emissions Using Fixed and Variable Fertilization Rates
}

\author{
Marius Kazlauskas *(D), Indrè Bručienè, Algirdas Jasinskas and Egidijus Šarauskis (D) \\ Institute of Agricultural Engineering and Safety, Agriculture Academy, Vytautas Magnus University, \\ Studentu 15A, Akademija, LT-53362 Kaunas Distr., Lithuania; indre.bruciene@vdu.lt (I.B.); \\ algirdas.jasinskas@vdu.lt (A.J.); egidijus.sarauskis@vdu.lt (E.Š.) \\ * Correspondence: marius.kazlauskas@vdu.lt; Tel.: +370-612-40119
}

Citation: Kazlauskas, M.; Bručienè,

I.; Jasinskas, A.; Šarauskis, E.

Comparative Analysis of Energy and GHG Emissions Using Fixed and Variable Fertilization Rates. Agronomy 2021, 11, 138. https://doi.org/ 10.3390/agronomy11010138

Received: 16 November 2020 Accepted: 10 January 2021 Published: 13 January 2021

Publisher's Note: MDPI stays neutral with regard to jurisdictional clai$\mathrm{ms}$ in published maps and institutional affiliations.

Copyright: (C) 2021 by the authors. Licensee MDPI, Basel, Switzerland. This article is an open access article distributed under the terms and conditions of the Creative Commons Attribution (CC BY) license (https:// creativecommons.org/licenses/by/ $4.0 /)$.

\begin{abstract}
Reducing the overuse of mineral fertilizers in crop production is a key factor related to healthier soil, healthier food, and more economical, efficient, and cleaner agricultural production. The aim of this study was to investigate and to compare the effects of fixed and variable rate fertilization with fertilizer consumption, energy consumption, and environmental impact. A 4-year experimental field study using crop rotation of four plants (spring barley, winter oilseed rape, winter wheat, and faba bean) was performed. Fertilization with phosphorus and potassium at a variable rate were performed and applied based on the soil properties analyzed before the start of the research and completion of the fertilization maps. Nitrogen fertilization was performed by additional fertilization using a proximal N-sensor, which gives the accurate nitrogen uptake in plants in real-time. This was followed by a comparative evaluation analysis of variables and conventional fixed-rate fertilization methods to assess fertilizer consumption, energy consumption, environmental impact, and economic efficiency. The results of the study showed that an application of a variable fertilization rate can reduce the total amount of nitrogen, phosphorus, and potassium fertilizers by $24.9 \%$, energy consumption by $3463.1 \mathrm{~kg} \mathrm{ha}^{-1}$, and emissions of greenhouse gases (GHG) by $341.5 \mathrm{~kg} \mathrm{CO}_{2 \mathrm{eq}}$ ha ${ }^{-1}$ compared to fixed fertilization rate. The method of fertilization with a variable application rate reduced the costs of fertilization, and at the same time, the costs of the total plant production by $€ 168.0 \mathrm{ha}^{-1}$, on average.
\end{abstract}

Keywords: precision fertilization; soil properties; nitrogen; phosphorus; potassium; map; crop rotation; GHG emission reduction; energy saving

\section{Introduction}

Plant nutrition is one of the most important factors on which the yield and the quality of agricultural products depend [1]. Therefore, organic and mineral fertilizers are used to enrich the soil with nutrients and to achieve the highest soil fertility. Over the last few decades, fertilizer use has been growing exponentially around the world. In 2018, global consumption of chemical and mineral fertilizers amounted to 188 million tons, of which nitrogen $(\mathrm{N})$ averaged $58 \%$, phosphorus $\left(\mathrm{P}_{2} \mathrm{O}_{5}\right) 22 \%$, and potassium $\left(\mathrm{K}_{2} \mathrm{O}\right) 21 \%$. In a period of 18 years (2000-2018), fertilizers' consumption increased by about $40 \%$ [2]. In Europe, fertilizers per crop area increased by $10 \%$ during this period and reached $77 \mathrm{~kg}^{-1}, \mathrm{~N}-49$, $\mathrm{P}_{2} \mathrm{O}_{5}-13$, and $\mathrm{K}_{2} \mathrm{O}-15 \mathrm{~kg}^{-1}$, respectively [2]. Intensive use of mineral fertilizers and application of conventional fertilization methods have negative effects on the soil, the environment, and human health. For example, ammonia emission from over-fertilized lands can damage organisms living in lakes and reservoirs, and the amount of nitrate concentration in drinking water can increase as well. Excessive amounts of fertilizers are related to higher GHG emissions [1,3]. Traditionally, fertilizers are applied to all arable land, regardless of soil variation in the field area [4]. Variable rate fertilization (VRF) is essential for the implementation of precision farming and for the efficient use of mineral fertilizers and nutrient management in plants adapted to the conditions of individual field sites [5]. It should be taken into consideration that the application of VRF usually 
requires prior knowledge of the field characteristics. This method often relies on accurate soil sampling and/or monitoring and analysis of crop yields for a specific field site [6].

The most important aim of precision agriculture is to adapt agricultural technological processes to the conditions of individual field locations. Precision farming can be defined as the longitudinal experience of farmers in order to ensure the sustainability of agriculture, based on four eligibility criteria: Application of the right method, the right rate of materials, the right choice of time, and the right application place [3,7-9].

Precision agriculture and VRF are closely linked to smart digital technologies such as Global Navigation Satellite Systems (GNSS), Remote Sensing (RS), Geographic Information Systems (GIS), crop or soil mapping tools, machine learning, and remote and proximal sensors capable of measuring and predicting crop and soil properties in real-time [3,5,10-14].

Agriculture is one of the economic sectors influencing climate change and directly or indirectly causing greenhouse gas (GHG) emissions. The agricultural sector is responsible for approximately $25 \%$ of $\mathrm{CO}_{2}, 50 \%$ of $\mathrm{CH}_{4}$, and $70 \%$ of $\mathrm{N}_{2} \mathrm{O}$ emissions worldwide. It contributes to approximately $13.5 \%$ of total anthropogenic GHG emissions [15,16]. Nitrous oxide $\left(\mathrm{N}_{2} \mathrm{O}\right)$ is a major product of GHG in intensive agriculture [17]. The concentration of $\mathrm{N}_{2} \mathrm{O}$ has a 310 times higher warming potential than $\mathrm{CO}_{2}$. The aim of agricultural management is to apply less $\mathrm{N}$ fertilizers without decreasing crop yields and to reduce $\mathrm{N}_{2} \mathrm{O}$ emissions and nitrate leaching from agriculture, and minimizing the negative impact for the environment [18]. The abundant use of $\mathrm{N}$ fertilizers increases the yield, but the application efficiency remains low. It can lead to environmental problems related to nitrate leaching and atmosphere pollution with nitrous oxide [19]. Only up to $50 \%$ of synthetic $\mathrm{N}$ fertilizers applied in agriculture in the US are assimilated by plants, and the rest is leached from the soil as $\mathrm{NO}_{3}$, causing surface and groundwater pollution, or emitted to the atmosphere as $\mathrm{NH}_{3}, \mathrm{~N}_{2}$, or $\mathrm{N}_{2} \mathrm{O}$ [20]. Rogovska et al. [20] claimed that accurate nitrogen fertilizer management can improve the efficiency of $\mathrm{N}$ fertilizer use while reducing farmers' costs and the environmental impact of crop production. The application of precision agricultural technologies can contribute to the reduction of GHG emissions, have a positive impact on farm productivity, and the economy [16]. Nawar et al. [21] conducted a review of different soil nutrient management zones for variable fertilization and found that the application of such methods is much more efficient and has a lower environmental impact compared to traditional fixed rate application methods. The authors note that there is not enough information in the agricultural studies regarding the cost-benefit analysis of VRF application based on management zones compared to fixed rate fertilization.

Remote (satellites, drones) and proximal (Green Seeker, Crop Circle, Crop Spec) sensing of crop to determine $\mathrm{N}$ nutrient status were presented by Tremblay [22], and handheld sensors Dualex Scientific ${ }^{\mathrm{TM}}$ (FORCE-A, Orsay, France), SPAD (Konica Minolta, Tokyo, Japan) that were used to evaluate $\mathrm{N}$ demand were described by Ferguson [23]. Burton et al. [24] investigated the use of different types of optic sensors Vis-IR, ATRand Raman spectroscopy (CRAIC Technologies, San Dimas, USA) to measure soil chemical properties in the field. Saiz-Rubio and Rovira-Mas [25] reviewed the current state of advanced farm management systems, reviewing each essential step, from data collection in crop fields to the application of a variable rate to enable growers to make optimal decisions while saving money and protecting the environment.

The research on precision fertilization with variable rate application can already be found in agricultural journals: Utilization of variable rate nitrogen to improve nitrogen use efficiency [18], application and economic assessment of variable rate fertilizer in wheat [4], phosphorus and potassium precision fertilization [26]. However, a comprehensive analysis of fertilizer demand, energy, economic, and environmental impact of different fertilization methods using long-term crop rotation is still lacking. The aim of this work was to investigate and to compare the effects of two fertilization methods, i.e., fixed rate used in conventional farming practice and variable rate, applied after analyzing the soil and assessing the changes in fertilizer consumption, energy consumption, GHG emissions, and economic costs related to fertilizers. 


\section{Materials and Methods}

\subsection{Experiment Site and Design}

Field experimental studies were conducted in 2015-2019 in the northern part of Lithuania $\left(56^{\circ} 10.109^{\prime} \mathrm{N}, 23^{\circ} 39.9848^{\prime} \mathrm{E}\right)$, on a farm in the Joniškis district (Figure 1$)$. The crops were grown according to the following crop rotation: Spring barley (Hordeum vulgare L.) variety Propino (2016, seeding time 8 April 2016), winter oilseed rape (Brassica napus L.) variety Visby (2017, 28 August 2016), winter wheat (Triticum aestivum L.) variety Skagen (2018, 30 August 2017), and faba beans (Vicia faba L.) variety Fuego (2019, 8 April 2019). The soil was described as sandy to silty loam according to the soil granulometric classification [27]. Experimental studies were performed comparing 2 different fertilization methods. The fixed fertilization rate (FRF) was determined using the recommended fertilizer rates based on the assumed yield for each crop. The variable fertilization rate (VRF) was determined based on soil characteristics in site-specific areas, crop assumed yield, and nutrient requirements for each crop.

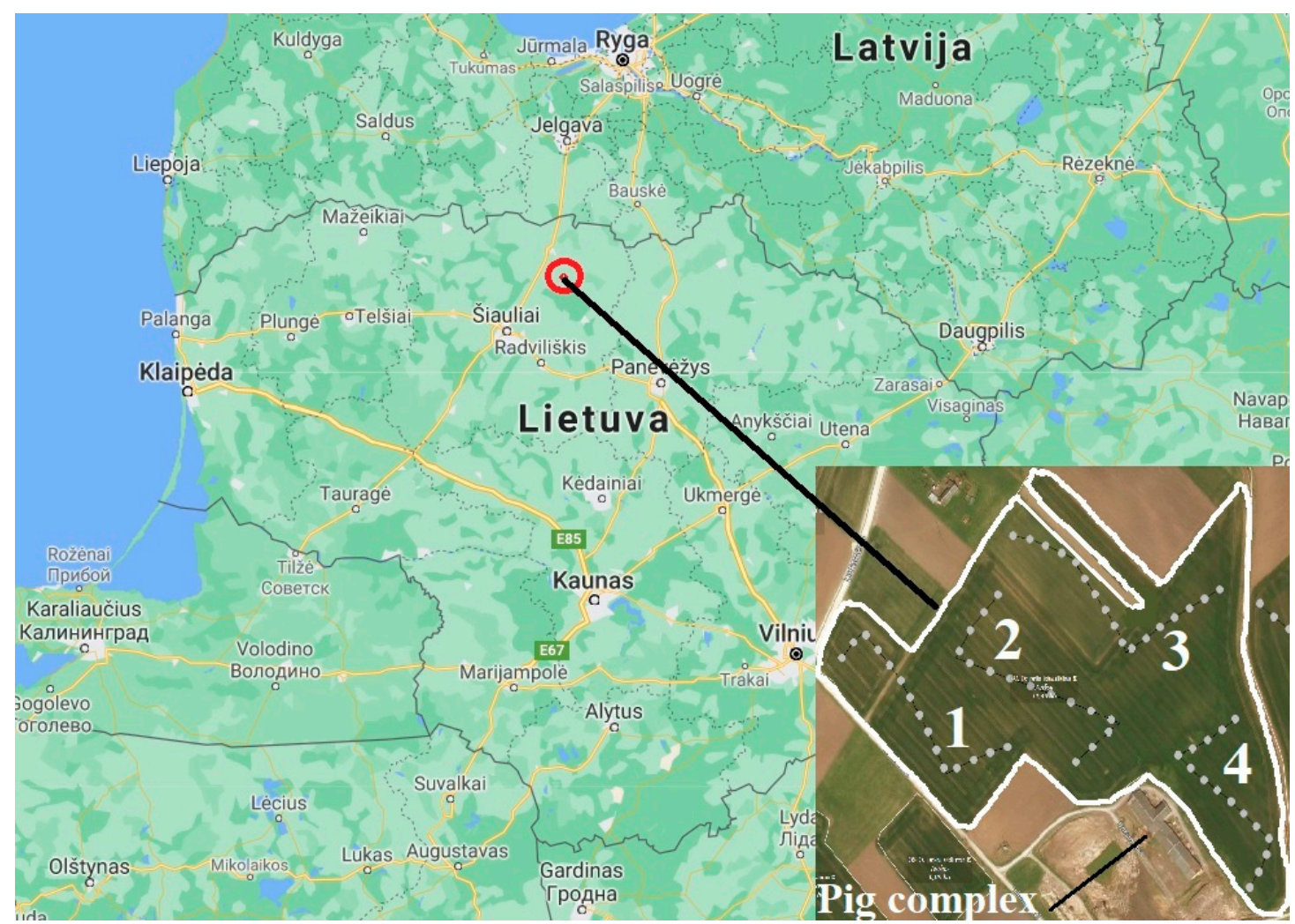

Figure 1. Experiment site location. Sample tracks with numbers and subsample points.

Average (2016-2019) annual precipitation was $505.7 \mathrm{~mm}$, and the average annual air temperature was $+8.0^{\circ} \mathrm{C}$ (meteo.lt). During plant vegetation in July 2018, the highest average monthly temperature of $+20.8^{\circ} \mathrm{C}$ was recorded. The lowest temperature $-7.7^{\circ} \mathrm{C}$ was observed in January 2016. The driest year was 2018, and the wettest year 2016. The dynamics of temperature and precipitation in 2016-2019 is shown in Figure 2. 


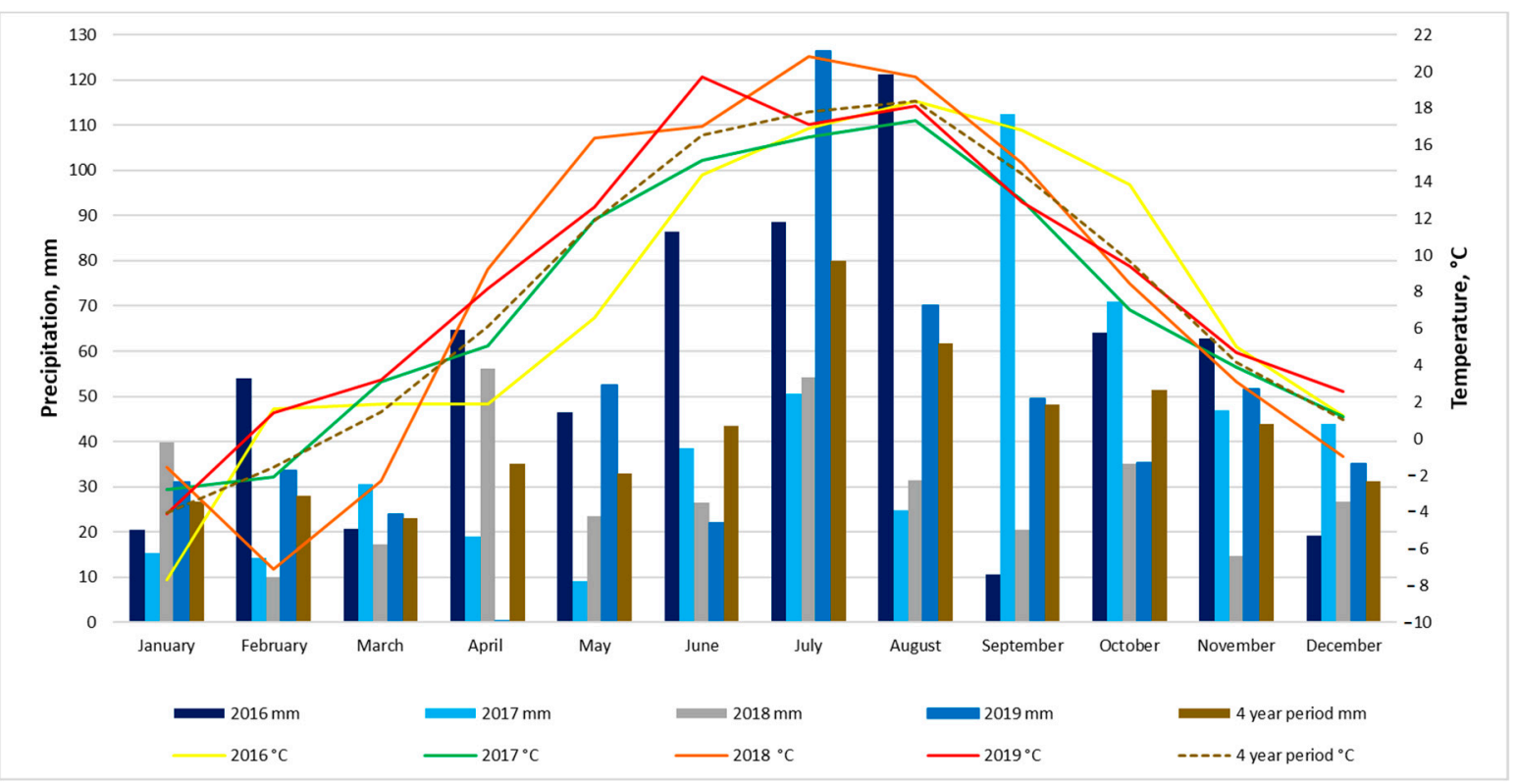

Figure 2. Monthly air temperature and precipitation in the period 2016-2019.

Field boundaries were measured on 16 September 2015, with an off-road vehicle Toyota Hilux (Toyota Motor Corporation, Toyota, Japan). The total field size was determined to be 11.37 ha by using the GPS coordinate positioning equipment Trimble EZ-Guide 250 with GPS antenna (Trimble Navigation Ltd., Alpharetta, GA, USA). John Deere 6630 tractor (John Deere GmbH \& Co., Mannheim, Germany), spreader Rauch Axis-H (Rauch Landmaschinenfabrik GmbH, Sinzheim, Germany), Rauch spreader terminal CCI 100 (Müller $\mathrm{GmbH}$, Rheinfelden, Germany) were used to spread the fertilizer according to variable rate fertilization maps. The crop was harvested with a John Deere S685 harvester (John Deere GmbH \& Co.KG, Zweibrücken, Germany) with a working width of $9.14 \mathrm{~m}$.

\subsection{Measurements of Soil Electrical Conductivity, Field Subdivision, and Soil Sampling}

Prior to the start of the experiment, soil apparent electrical conductivity (ECa) was measured using an EM-38 MK-2 (Geonics Ltd., Mississauga, Canada) at a depth of 0-1.5 m in the vertical position to determine differences in the field soil's properties and to establish an accurate soil sampling plan. EM-38 readings were applied while driving a Toyota off-road vehicle towing EM38-MK2 mounted on plastic sledges at a speed of $10-15 \mathrm{~km} \mathrm{~h}^{-1}$ in parallel technological tracks, separated by $30 \mathrm{~m}$, with a total of 1046 readings ( 92 readings ha $^{-1}$ ) for the field of $11.37 \mathrm{ha}$. These readings were stored on a computer Panasonic Toughbook CF 19 (Panasonic Corporation, Osaka, Japan).

ECa readings were converted to a CSV file format using Convert EM38-MK2 software, and subsequently, an ECa map (Figure 3) was created using the Open Source Geographic Information System (QGIS) program. A total of 4 areas (each approximately 3 ha) with different ranges of ECa were delineated (Figure 1). The delineated plots in a digital shape (SHP) file was sent back to the field computer, and soil samples were taken. 


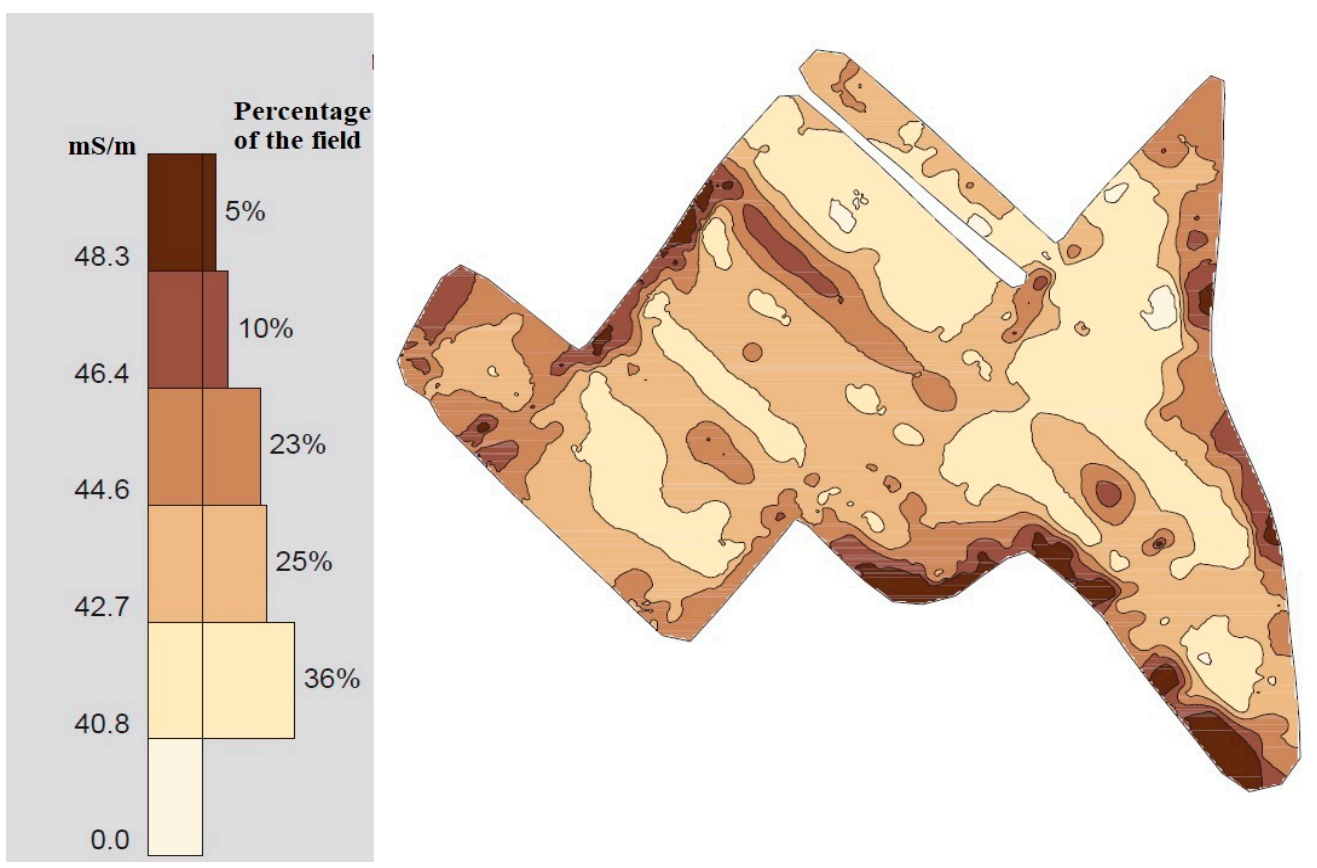

Figure 3. ECa map representing differences of the soil properties in the field.

Soil (at a depth of 20-30 cm) was sampled on 17 September 2015 and 2 September 2019 using an automatic soil sampling equipment (Figure 4) developed by Agricon $(\mathrm{GmbH}$, Jahna, Germany) and manufactured by Adigo AS, Langhus, Norway). The subsamples were collected while driving non-stop (50\% more efficient than sampling at a stop [28]) in the trajectory of the letter $\mathrm{Z}$ and combined in one sample in each of the 4 homogeneous areas delineated previously.

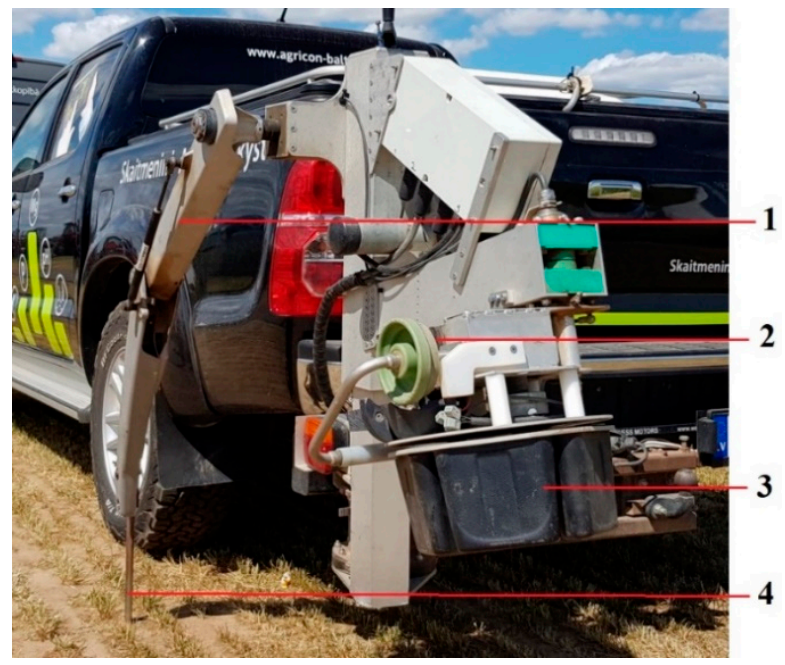

Figure 4. Automatic soil sampling equipment: 1-automatically operated mechanical hand; 2 -needle cleaning mechanism; 3-boxes for collecting soil samples; 4-a needle for taking soil samples from a depth of $20-30 \mathrm{~cm}$.

Four samples were taken from 4 areas formed according to soil ECa differences. One sample consisted of 15-20 subsamples (Figure 1). These samples were collected into boxes containing 300-500 g of soil. After all the boxes were filled, soil samples from each box were placed into separate plastic bags, and labeled with a bar code including information, such as the coordinates, date, and time of sampling. Samples were sent to an accredited laboratory Agrolab GmbH (Leinefelde-Worbis, Germany), where their 
granulometric structure, magnesium $(\mathrm{Mg})$ and $\mathrm{pH}\left(\mathrm{CaCl}_{2}\right.$ method), potassium $(\mathrm{K})$ and phosphorous (P) (CAL method) were determined.

\subsection{Determination of Fixed and Variable Fertilization Rates for Phosphorus and Potassium}

In order to apply the fertilizer at a variable rate, fertilization plans were drawn up (Figure 5). Results of the soil analysis were imported into an agronomic software Agriport. Then, variable fertilizer application rates for a 4-year crop rotation were calculated using the data from soil analysis, the uptake of nutrients $\mathrm{P}$ and $\mathrm{K}$ for each crop and its assumed yield $\left(\mathrm{t} \mathrm{ha}^{-1}\right)$, respectively: Spring barley $\left(7 \mathrm{t} \mathrm{ha}^{-1}\right) \mathrm{P}_{2} \mathrm{O}_{5}-33 \mathrm{~kg} \mathrm{ha}^{-1}$, $\mathrm{K}_{2} \mathrm{O}-25.7 \mathrm{~kg} \mathrm{ha}^{-1}$; winter rape $\left(5 \mathrm{tha}^{-1}\right) \mathrm{P}_{2} \mathrm{O}_{5}-33 \mathrm{~kg} \mathrm{ha}^{-1}, \mathrm{~K}_{2} \mathrm{O}-25.7 \mathrm{~kg} \mathrm{ha}^{-1}$; winter wheat $\left(8 \mathrm{t} \mathrm{ha}^{-1}\right) \mathrm{P}_{2} \mathrm{O}_{5}-33 \mathrm{~kg} \mathrm{ha}^{-1}, \mathrm{~K}_{2} \mathrm{O}-25.7 \mathrm{~kg} \mathrm{ha}^{-1}$; faba beans $\left(4 \mathrm{tha}^{-1}\right) \mathrm{P}_{2} \mathrm{O}_{5}-33 \mathrm{~kg} \mathrm{ha}^{-1}$, $\mathrm{K}_{2} \mathrm{O}-25.7 \mathrm{~kg} \mathrm{ha}^{-1}$. The maps for $\mathrm{P}$ and $\mathrm{K}$ fertilization for the computer of Rauch spreader were created in a SHP file also using Agriport online program. In order to generate a variable rate fertilization (VRF) map for each element, soil analysis was loaded into the program. Then, crop rotation and assumed yield of each crop were entered into the program, which automatically generated VRF maps for each fertilizer. Fertilizers $\mathrm{P}$ and $\mathrm{K}$ were spread at a variable rate according to the fertilization map, distributing $25 \%$ of the planned 4 -year fertilization rate in each year. Magnesium was enough to satisfy crop demand in the whole rotation and was not applied.

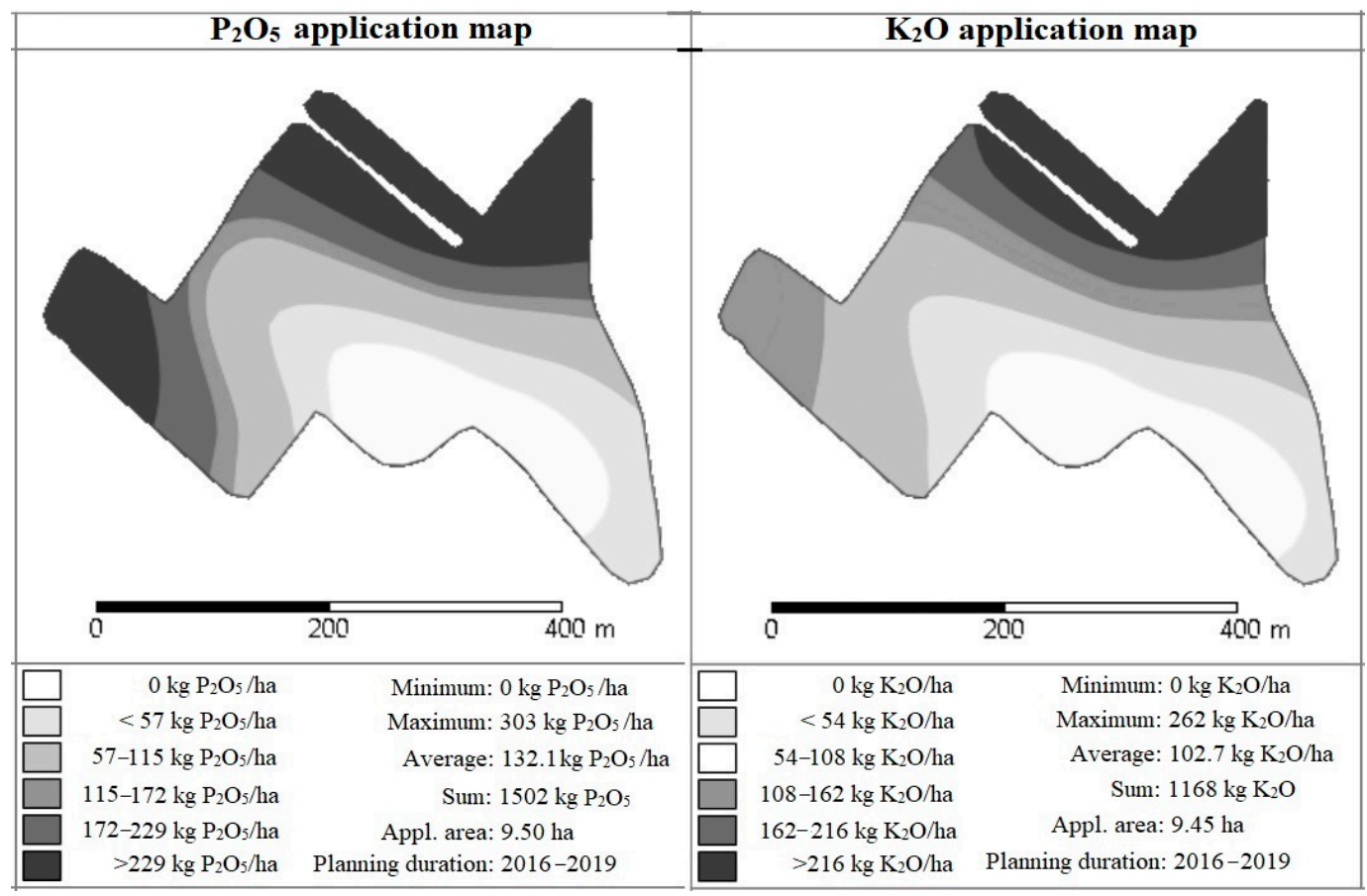

Figure 5. $\mathrm{P}_{2} \mathrm{O}_{5}$ and $\mathrm{K}_{2} \mathrm{O}$ application maps for 2016-2019 crop rotation.

Fixed rates of fertilization (FRF) for nutrients $\mathrm{P}$ and $\mathrm{K}$ were calculated using the data from the agronomic software Agriport only for nutrient uptake for each crop and assumed yield, respectively: For spring barley $\left(7 \mathrm{tha}^{-1}\right) \mathrm{P}_{2} \mathrm{O}_{5}-56 \mathrm{~kg} \mathrm{ha}^{-1}, \mathrm{~K}_{2} \mathrm{O}-42 \mathrm{~kg} \mathrm{ha}^{-1}$; for winter rape $\left(5 \mathrm{t} \mathrm{ha}^{-1}\right) \mathrm{P}_{2} \mathrm{O}_{5}-89.3 \mathrm{~kg} \mathrm{ha}^{-1}, \mathrm{~K}_{2} \mathrm{O}-49.8 \mathrm{~kg} \mathrm{ha}^{-1}$; for winter wheat $\left(8 \mathrm{tha}^{-1}\right) \mathrm{P}_{2} \mathrm{O}_{5}-$ $64 \mathrm{~kg} \mathrm{ha}^{-1}, \mathrm{~K}_{2} \mathrm{O}-48 \mathrm{~kg} \mathrm{ha}^{-1}$; for faba beans $\left(4 \mathrm{tha}^{-1}\right) \mathrm{P}_{2} \mathrm{O}_{5}-47.6 \mathrm{~kg} \mathrm{ha}^{-1}, \mathrm{~K}_{2} \mathrm{O}-56 \mathrm{~kg} \mathrm{ha}^{-1}$.

\subsection{Yara N-Sensor ALS Calibration}

Before starting to fertilize winter wheat in the field, a manual proximal sensor Yara $\mathrm{N}$-tester (manufactured by Konica Minolta INC, Japan with Yara software) was used to calibrate the proximal Yara N-Sensor ALS (manufactured by Tec5 GmbH, Germany and developed by Yara International ASA, Oslo, Norway). Calibration was needed to set 
the $\mathrm{N}$ application rate for the Skagen variety of winter wheat at certain growth stages $(\mathrm{BBCH} 30 ; 37)$ in a repeatable part of the field. Yara N-Sensor ALS can collect data only to determine $\mathrm{N}$ uptake in the crop and cannot recommend $\mathrm{N}$ application rate. An $\mathrm{N}$ tester helps to determine $\mathrm{N}$ optimum application rate for different wheat varieties. The calibration location for the device was selected after a visual assessment of the winter wheat field after entering the 4th technological track from the field edge. Measurements were performed by randomly selecting the middle part of the fully developed last leaves of 30 different plants in the $20 \mathrm{~m}$ technological track section (Figure 6). The area measured with the N-tester was scanned with Yara N-Sensor ALS device to complete the calibration process. Then, the $\mathrm{N}$ application rate for the winter wheat was entered into the terminal using the $\mathrm{N}$ application program in the tractor and this software adjusted the $\mathrm{N}$ rate in site-specific areas in real-time while driving in the field.

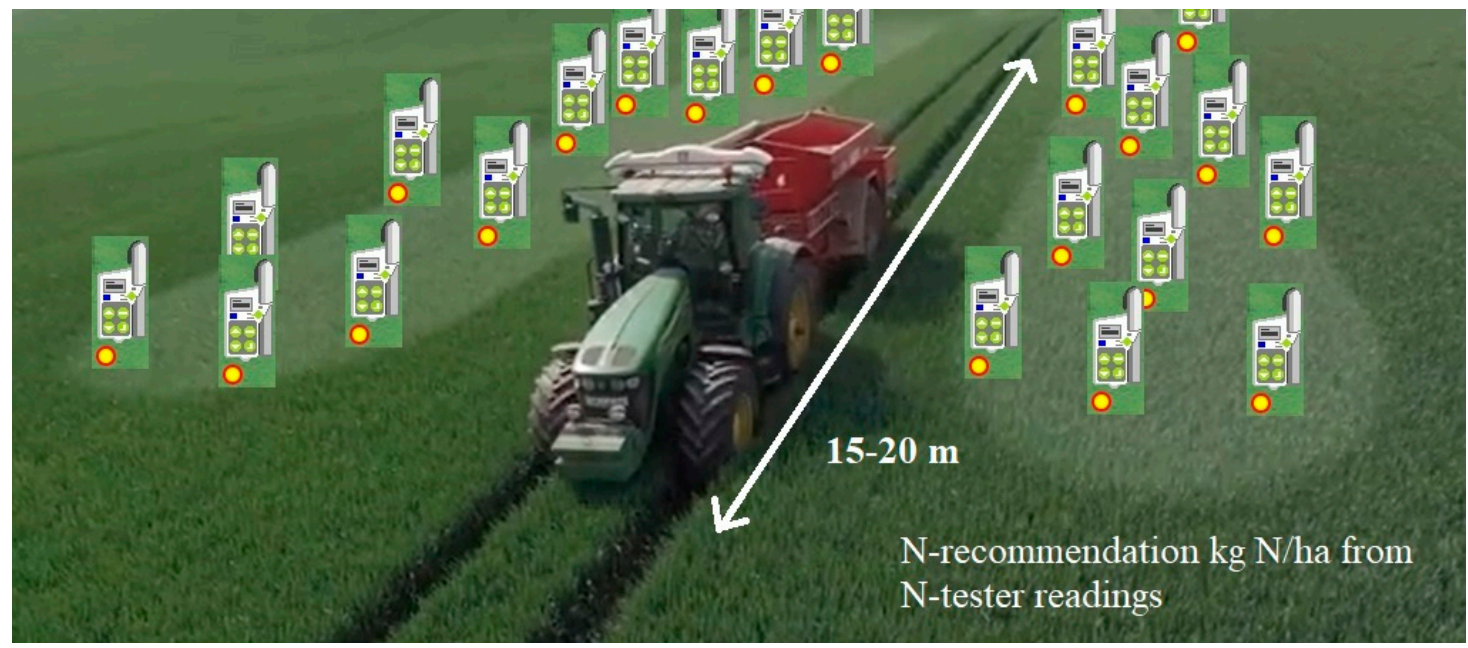

Figure 6. Yara N-Sensor ALS calibration using hand N-tester in the field.

\subsection{Fixed and Variable Rate Application for Nitrogen Fertilization}

The FRF method was not performed in the field as an actual comparison. FRF for $\mathrm{N}$ nutrient was calculated based on conventional farming experience for spring barley $\mathrm{N}-50 \mathrm{~kg} \mathrm{ha}^{-1}$, winter oilseed rape $\mathrm{N}-188 \mathrm{~kg} \mathrm{ha}^{-1}$, winter wheat $\mathrm{N}-210 \mathrm{~kg} \mathrm{ha}^{-1}$, and faba beans $\mathrm{N}-70.2 \mathrm{~kg} \mathrm{ha}^{-1}$, respectively. For the first $\mathrm{N}$ application for winter wheat $\mathrm{N}-40 \mathrm{~kg} \mathrm{ha}^{-1}$ (BBCH 23), and for winter oilseed rape $\mathrm{N}-60 \mathrm{~kg} \mathrm{ha}^{-1}$ (BBCH 18), fixed rates were calculated based on conventional farming experience also when using VRF method. For the first N application, it was not possible to use the Yara N-Sensor ALS since it could not collect data from the poor biomass of the crops. For spring barley and faba beans, fixed $\mathrm{N}$ nutrient rates were calculated according to conventional farming experience and applied only once before seeding using a fixed rate.

VRF additional application was made only 2 times at different growth stages: For winter wheat $\mathrm{N}-84 \mathrm{~kg} \mathrm{ha}^{-1}$ (BBCH 30) and $\mathrm{N}-75 \mathrm{~kg} \mathrm{ha}^{-1}$ (BBCH 37); for winter oilseed rape $\mathrm{N}-72 \mathrm{~kg} \mathrm{ha}^{-1}$ (BBCH 25) and N-43 kg ha ${ }^{-1}$ (BBCH 41).

Yara N-Sensor ALS agronomic software calculated the actual N-uptake of the crop. Using $\mathrm{N}$ application software optimum rates for VRF in site-specific areas were derived from the N-uptake data in the crop. Calculated rates were sent to the spreader controller, which adjusted the shutters of the implement. At that time, the N-sensor was installed on the roof of the tractor, scanning the crop in $4 \mathrm{~m}$ stripes on both sides when driving at $30 \mathrm{~m}$ width tramlines.

Information about the fertilizers applied and the amount of $\mathrm{N}$ absorbed by the plants in individual parts of the field was transmitted online from the computer inside the tractor to the Agriport program into the office computer. Fertilizer rates for each part of the field and an average could be seen in this program. In our case, $\mathrm{N}$ fertilizers YaraBela 
AXAN NS 27-4 and YaraBela SULFAN NS 24-6 were applied at an average variable rate: For oilseed rape (2017) N-72 kg ha ${ }^{-1}$ (300 kg ha ${ }^{-1}$ YaraBela SULFAN) at BBCH 25 and $\mathrm{N}-43 \mathrm{~kg} \mathrm{ha}^{-1}$ (179 $\mathrm{kg} \mathrm{ha}^{-1}$ YaraBela SULFAN) at BBCH 41 growth stages; for winter wheat (2018) N-84 kg ha ${ }^{-1}$ (311 kg ha ${ }^{-1}$ YaraBela AXAN) at BBCH 30 and N-75 kg ha-1 (278 kg ha ${ }^{-1}$ YaraBela AXAN) at BBCH 37 growth stages.

\subsection{Assessment of Energy Use and GHG Emissions}

Fertilizer energy consumption (MJ ha ${ }^{-1}$ ) using variable rate fertilization (VRF) and fixed rate fertilization (FRF) was calculated by multiplying the amount of fertilizer used by the energy equivalent the $\mathrm{N}$ fertilizer $\left(60.6 \mathrm{MJ} \mathrm{kg}^{-1}\right)$ [29]. Energy consumption equivalents for $\mathrm{P}_{2} \mathrm{O}_{5}$ and $\mathrm{K}_{2} \mathrm{O}$ are presented in Table 1. In order to compare fertilization methods, the difference in energy consumption between VRF and FRF was calculated. Another very important benchmark that has been identified was the reduction of fertilizers energy consumption per ton of crop. Fixed and variable fertilizer rates were calculated for an assumed average yield using yield historical data in this field from the last 4 years for each crop: $7.0 \mathrm{t} \mathrm{ha}^{-1}$ for spring barley; $5.0 \mathrm{t} \mathrm{ha}^{-1}$ for winter oilseed rape; $8.0 \mathrm{t} \mathrm{ha}^{-1}$ for winter wheat; $4.0 \mathrm{t} \mathrm{ha}^{-1}$ for faba beans. Therefore, such yields were used in further calculations. In this field, the last historical yields were received using a fixed application rate based only on nutrient uptake with the yield. For our study, it was important in 4 year crop rotation to get the same yield with a lower application rate, which was based not only on nutrient uptake with the yield but also using data about nutrient stocks in the soil. In the farming business, the main goal should be to get more profit, but not the highest yields. This can be achieved using modern precision farming technologies like VRF.

Table 1. Equivalents of energy consumption and GHG emissions for basic fertilizers $[29,30]$.

\begin{tabular}{ccc}
\hline Fertilizers & $\begin{array}{c}\text { Energy Equivalent } \\
\left(\mathbf{M J ~ k g}^{-\mathbf{1}}\right)\end{array}$ & $\begin{array}{c}\text { GHG Emission Equivalent } \\
\mathbf{( k g ~ C O}_{\mathbf{2 e q ~}} \mathbf{~ k g ~}^{-\mathbf{1}} \mathbf{)}\end{array}$ \\
\hline $\mathrm{N}$ & 60.6 & 4.96 \\
$\mathrm{P}_{2} \mathrm{O}_{5}$ & 11.1 & 1.35 \\
$\mathrm{~K}_{2} \mathrm{O}$ & 6.7 & 0.58 \\
\hline
\end{tabular}

The environmental impact assessment identified GHG emissions $\left(\mathrm{kg} \mathrm{CO}_{2 \mathrm{eq}} \mathrm{ha}^{-1}\right)$ from different VRF and FRF fertilization methods. GHG emissions were calculated by multiplying the amount of fertilizer used for each method by the GHG equivalents $\left(\mathrm{kg} \mathrm{CO}_{2 \mathrm{eq}} \mathrm{kg}^{-1}\right)$ given in Table 1. According to Lal et al. $[29,30]$, the $\mathrm{CO}_{2}$ emission equivalent per kilogram of $\mathrm{N}$ fertilizers was 4.96 , for $\mathrm{P}_{2} \mathrm{O}_{5}$ and $\mathrm{K}_{2} \mathrm{O}$ were 1.35 and $0.58 \mathrm{~kg} \mathrm{CO}_{2} \mathrm{~kg}^{-1}$, respectively. The difference in GHG emissions for each fertilizer type between VRF and FRF methods was also calculated. In order to assess the environmental impact of different fertilization methods, the reduction of GHG emissions per ton of crop yield was calculated based on yield (for spring barley, winter oilseed rape, winter wheat, and faba beans 7.0, 5.0, 8.0, $4.0 \mathrm{tha}^{-1}$, respectively).

\subsection{Statistical Analysis}

To ensure the statistical reliability of the data, the soil properties and yield studies of each crop were performed in 4 replicates of random samples. Each soil sample consisted of randomized 15-20 subsamples. Experimental study data were processed using one-way analysis of variance program ANOVA. The data was evaluated by calculating the smallest significant difference with the level of statistical significance $(p<0.05)$ using Tukey's HSD method [31,32]. The different letters in Table 2 indicate the significant difference between the values. 
Table 2. Analysis of soil properties at the beginning of 2015 and at the end of 2019.

\begin{tabular}{|c|c|c|c|c|c|c|c|c|c|c|}
\hline \multirow[t]{2}{*}{ Sample No. } & \multicolumn{2}{|c|}{ Element $\mathrm{pH}$} & \multicolumn{2}{|c|}{$\begin{array}{l}\text { Element P mg } \\
100 \mathrm{~g}^{-1} \text { Soil }\end{array}$} & \multicolumn{2}{|c|}{$\begin{array}{c}\text { Element K mg } \\
100 \mathrm{~g}^{-1} \text { Soil }\end{array}$} & \multicolumn{2}{|c|}{$\begin{array}{c}\text { Element Mg mg } \\
100 \mathrm{~g}^{-1} \\
\text { Soil }\end{array}$} & \multicolumn{2}{|c|}{$\begin{array}{l}\text { Structure and } \\
\text { Soil Group }\end{array}$} \\
\hline & 2015 & 2019 & 2015 & 2019 & 2015 & 2019 & 2015 & 2019 & 2015 & 2019 \\
\hline 1 & $7.4 \mathrm{a}$ & $7.4 a$ & $9.1 \mathrm{a}$ & $7.9 \mathrm{e}$ & $16.4 a$ & $9.9 \mathrm{e}$ & $14.4 \mathrm{a}$ & $14.1 \mathrm{a}$ & & \\
\hline 2 & $7.2 \mathrm{a}$ & $7.3 a$ & $17.5 \mathrm{~b}$ & $16.6 b$ & $23.9 b$ & $14.0 \mathrm{f}$ & $18.7 \mathrm{~b}$ & $19.6 \mathrm{~b}$ & & \\
\hline 3 & $7.2 \mathrm{a}$ & $7.1 \mathrm{a}$ & $6.6 c$ & $8.2 \mathrm{ef}$ & $11.5 \mathrm{c}$ & $8.4 \mathrm{~g}$ & $15.3 \mathrm{a}$ & $16.5 d$ & & \\
\hline 4 & $7.1 \mathrm{a}$ & $7.2 \mathrm{a}$ & $59.9 d$ & $48.5 \mathrm{~g}$ & $41.3 \mathrm{~d}$ & $27.6 \mathrm{~h}$ & $23.9 \mathrm{c}$ & $23.5 c$ & & \\
\hline Average & 7.2 & 7.3 & 23.2 & 20.3 & 23.3 & 15.0 & 18.1 & 18.4 & & \\
\hline $\begin{array}{l}\text { Recommended interval for } \\
\text { optimum nutrient amount * }\end{array}$ & \multicolumn{2}{|c|}{$6.3-7.0$} & \multicolumn{2}{|c|}{$4.9-7.2$} & \multicolumn{2}{|c|}{$11.0-16.0$} & \multicolumn{2}{|c|}{$7.6-11.0$} & \multicolumn{2}{|c|}{ - } \\
\hline
\end{tabular}

Notes: Soil group sL/4 means sandy light loam, clay particles $(<0.002 \mathrm{~mm})>17-25 \%$, fine soil fractions $(<0.006 \mathrm{~mm})>23-35 \%$ [27]. Sample No. 4 was particularly different from other samples because this sampling area was close to the pig complex (Figure 1). ${ }^{*}$ Recommended interval means the optimum nutrient amount available for the most row crops in the soil according to its granulometric structure and soil group. The different letters indicate the significant difference between the values.

\section{Results and Discussion}

\subsection{Soil Analysis}

At the beginning of the research in 2015, the average of each element level in analyzed soil samples was above the optimum level (Table 2). At the end of the studies in 2019, the average $\mathrm{K}$ element concentration in the re-analyzed soil samples was reduced significantly (35.6\%) to the optimum level, but the rest of the elements stayed above. The main reason for K element reduction was due to the sampling area No. 3 because of higher biomass and yield. Increasing yield leads to higher K element uptake. Phosphorus concentration in all samples in the soil was in or above the optimum level. The highest concentration for elements $\mathrm{P}$ and $\mathrm{K}$ was found in sample No. 4.

$\mathrm{Mg}$ and $\mathrm{pH}$ levels in all samples were above the optimum level at the beginning and at the end of the study.

The amount of elements in the soil changed in all the samples throughout the 4-year period: $\mathrm{pH}$ increased on average by $1.4 \%, \mathrm{Mg}$ increase $-1.7 \%$, P decreased $-12.5 \%, \mathrm{~K}$ decreased$35.6 \%$, respectively (Figure 7). Results received from the laboratory were imported into agronomic software Agriport. All nutrient distribution maps were generated automatically using this program. Agriport has algorithms, which helps to interpolate the spaces between the different sampling areas with different soil sample results. This feature helps to get a better visual view of the nutrient distribution in the field.

Analogous studies by Kulczycki and Grocholski [26] at the start of experimental field research found very high levels of potassium in the soil, and the element potassium exceeded the recommended levels of $82 \%$ of the total area. After six years of potassium fertilization at a variable rate, marked changes were observed-38\% of the total field area was already attributed to the optimal element content in the soil, and very high potassium levels were found in only $18 \%$ of the field area. Meanwhile, the variable rate of phosphorus fertilization increased the field area with a low P element level by $9 \%$ and the medium element level by $6 \%$, but the field area with a high $P$ element level decreased by $7 \%$, and the very high $P$ element level decreased by $8 \%$, respectively. 


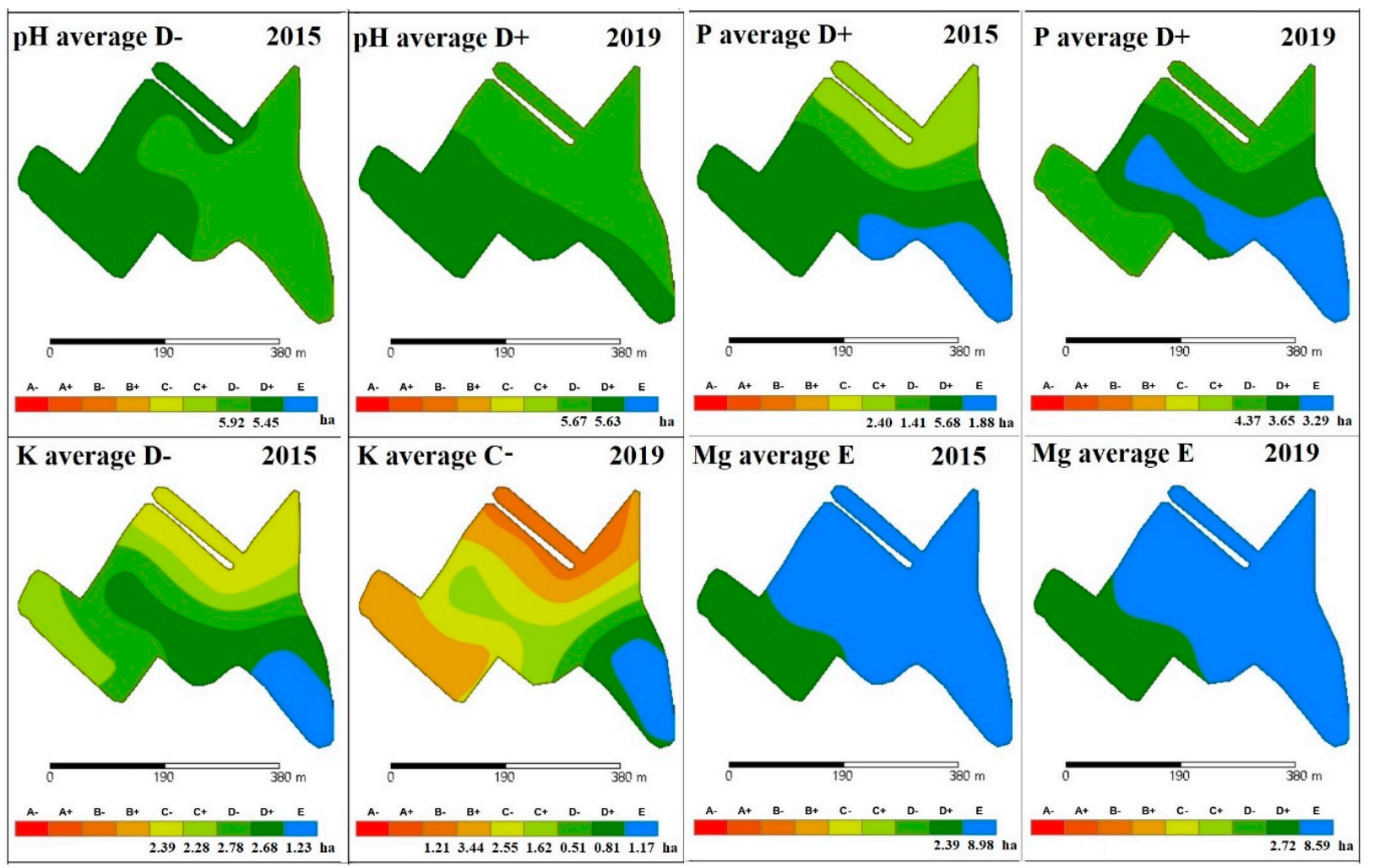

Figure 7. Distribution of soil elements $(\mathrm{pH}, \mathrm{P}, \mathrm{K}, \mathrm{Mg})$ according to the classes and the area. The class $\mathrm{C}$ or the optimal number of elements is yellowish and light green color; classes D and $\mathrm{E}$ are dark green and blue, indicating an excess of soil elements; letters A and B are red and brown, indicating the deficiency of elements. "+" next to a letter means higher and "-"-lower nutrient amount in the same element distribution class.

\subsection{Additional N-Variable Rate Fertilization of Winter Wheat}

This study presents additional fertilization of winter wheat at growth stages $\mathrm{BBCH}$ 30 and BBCH 37. In spring 2018, N uptake (Figure 8) and $\mathrm{N}$ fertilization maps (Figure 9) were generated with additional $\mathrm{N}$ fertilization at a variable rate in real-time with the Yara $\mathrm{N}$-Sensor ALS. $\mathrm{N}$ uptake was highest in $15.2 \%$ of the total area $\left(56-67 \mathrm{~kg} \mathrm{ha}^{-1}\right)$, and N application rate was lowest in $16.6 \%$ of the total area $\left(66-76 \mathrm{~kg} \mathrm{ha}^{-1}\right)$ (Figure $\left.8 \mathrm{a}\right)$. In the areas where crop $\mathrm{N}$ uptake was below the biomass threshold (17 $\mathrm{kg} \mathrm{ha}^{-1}$ at $\left.\mathrm{BBCH} 30\right)$, the fertilization rate was reduced from 66 to $0 \mathrm{~kg} \mathrm{ha}^{-1}$ (1.6\% of the total area).

During variable fertilization at $\mathrm{BBCH} 37$ (Figure $8 b$ ), the average $\mathrm{N}$ uptake of winter wheat was $108 \mathrm{~kg} \mathrm{ha}^{-1}$ and the average $\mathrm{N}$ fertilizer rate was $75 \mathrm{~kg} \mathrm{ha}^{-1}$. In the last additional fertilization, the field became more homogeneous. For example, when the $\mathrm{N}$ uptake went from 105 to $117 \mathrm{~kg} \mathrm{ha}^{-1}$, the field uniformity reached $84.3 \%$. The uniformity of the field ( $71 \%$ of the total area) also affected the fertilizer application rate, which ranged from 68 to $78 \mathrm{~kg} \mathrm{ha}^{-1}$. After 16 days, $\mathrm{N}$ fertilization change in $\mathrm{N}$ uptake at $\mathrm{BBCH} 37$ was on average $60 \mathrm{~kg} \mathrm{ha}^{-1}$. 


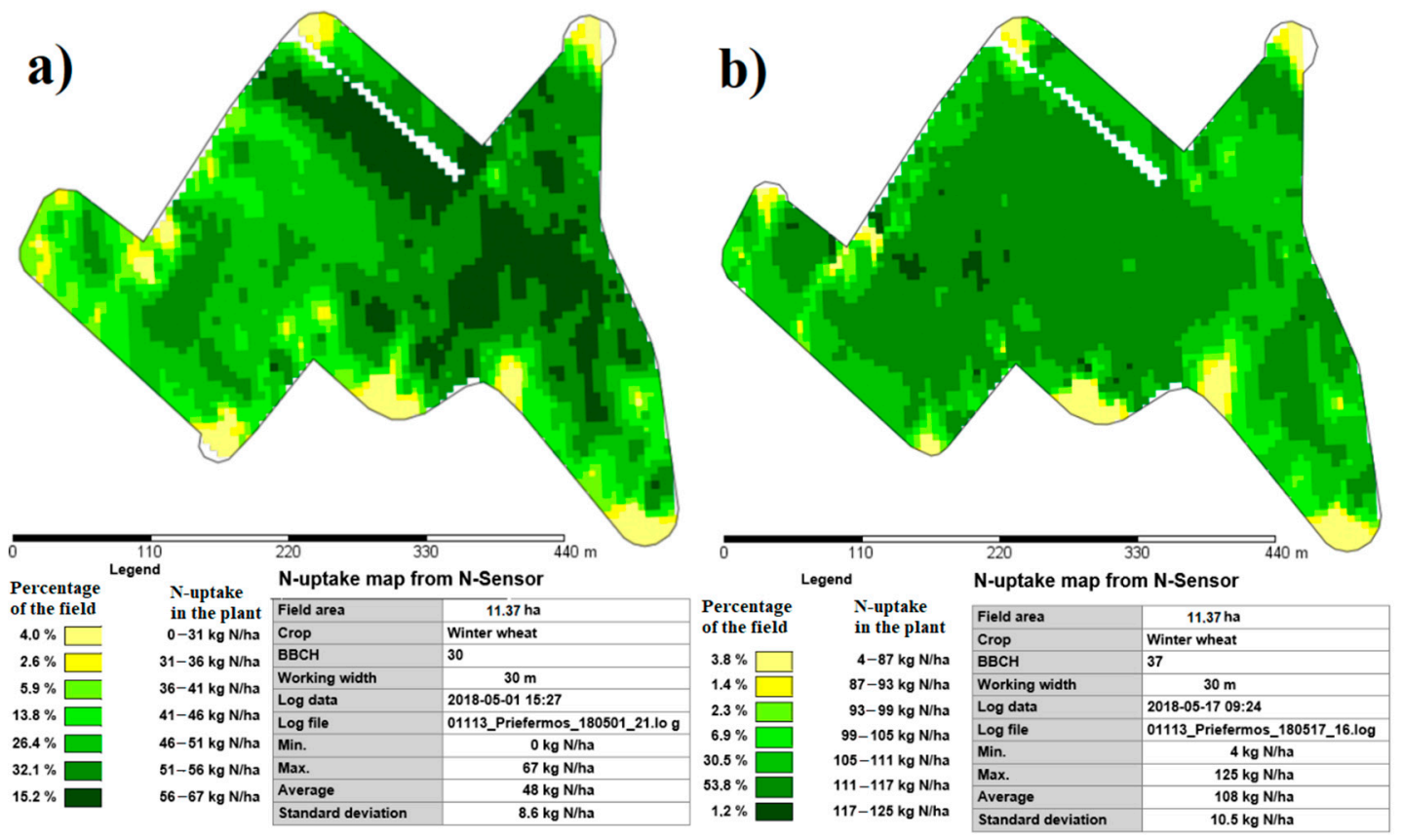

Figure 8. Maps of $\mathrm{N}$ uptake in winter wheat: (a) Date of data collection on 1 May 2018; (b) date of data collection on 17 May 2018.
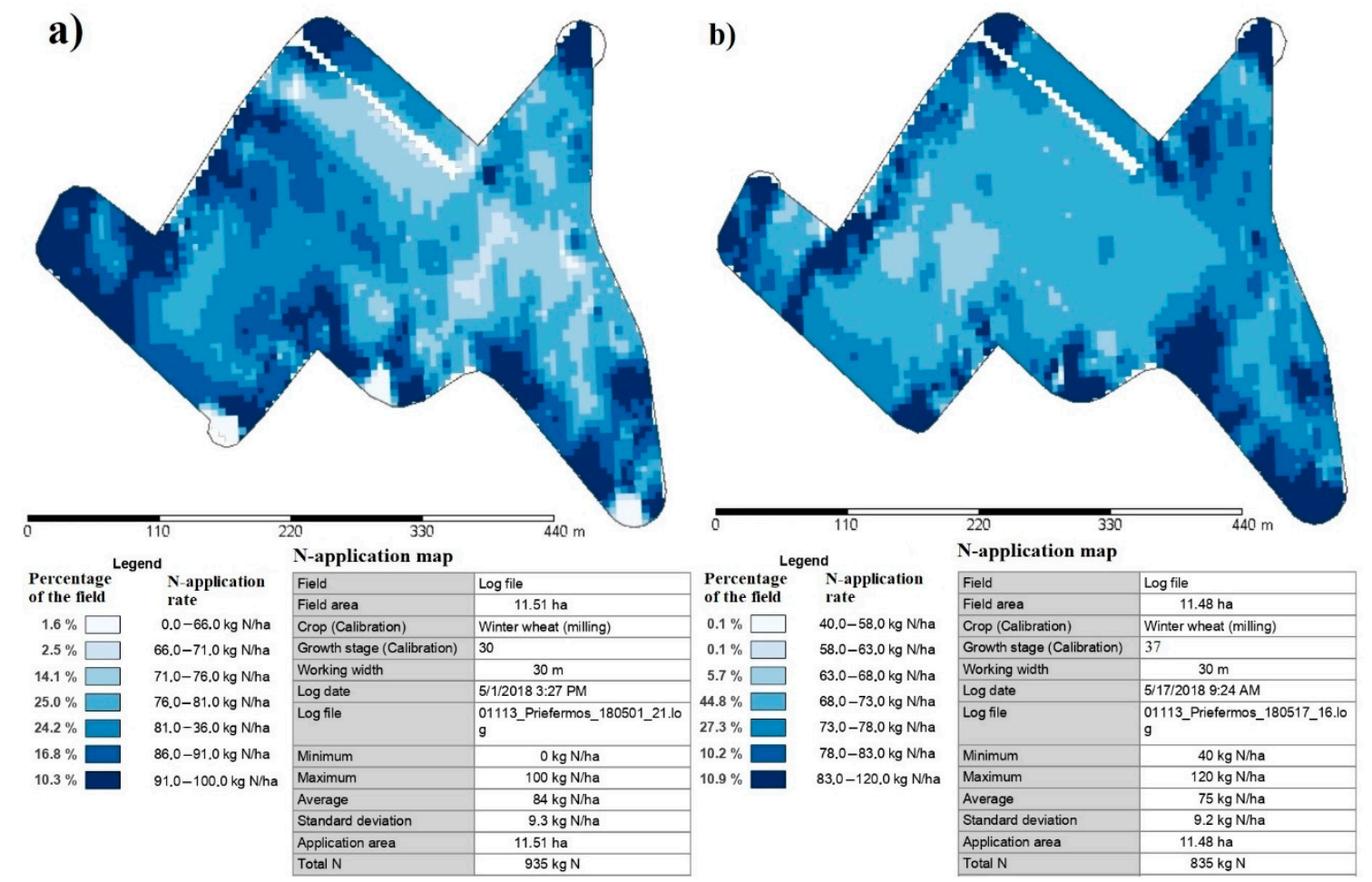

Figure 9. N fertilization maps of winter wheat: (a) Date of data collection on 1 May 2018; (b) date of data collection on 17 May 2018.

\subsection{Crop Yield}

For calculation of the demand of mineral fertilizer, energy, and pollution indicators, the average yields were determined using historical yield data in this field from the last 4 years for each crop in the crop rotation. The average yields for spring barley, winter oilseed rape, winter wheat, and faba beans were 7.0, 5.0, 8.0, and $4.0 \mathrm{t} \mathrm{ha}^{-1}$, respectively. 
These yields were taken as assumed and used in subsequent calculations as yields obtained using the FRF method. The average yields for the whole field using the VRF method for spring barley, winter oilseed rape, winter wheat, and faba beans were 7.3, 5.2, 8.1, and $3.9 \mathrm{tha}^{-1}$, respectively.

During the threshing of winter wheat, a precise yield map was created (Figure 10) and yield data were recorded: An average of $8.1 \mathrm{tha}^{-1}$, a minimum of $5.4 \mathrm{tha}^{-1}$, a maximum of $9.2 \mathrm{tha}^{-1}$. After comparing the yield map with the $\mathrm{N}$ uptake map, it can be seen that the highest yield was in the places with the lowest $\mathrm{N}$ application rate, because in this site, specific areas contained more available $\mathrm{N}$ nutrients than other areas. During the application of variable $\mathrm{N}$ fertilization in the places where the maximum rate of $220 \mathrm{~kg} \mathrm{ha}^{-1}$ was applied, the lowest yield was $5.4 \mathrm{tha}^{-1}$. The reason could be that these site-specific areas had lower $\mathrm{N}$ availability in the soil. The $\mathrm{N}$ uptake map made at growth stage $\mathrm{BBCH}$ 37 showed more even nitrogen distribution in the crop matching to the yield map with smaller yield variability in the field. In $64 \%$ of the total area, the yield uniformity ranged from 6.8 to $8.4 \mathrm{tha}^{-1}$.

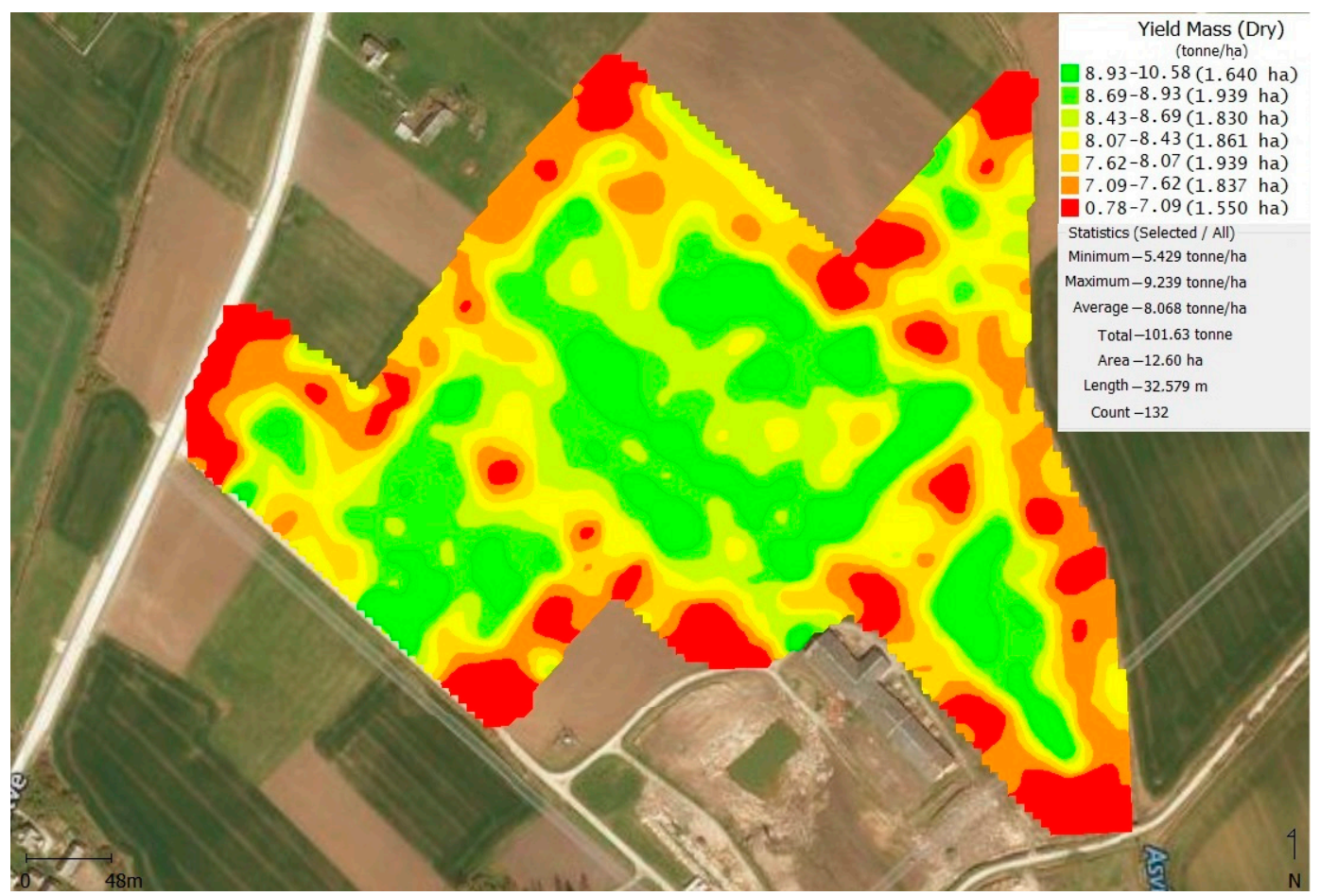

Figure 10. Winter wheat yield map.

The threshing speed of the combine was uniform and accounted for $68 \%$ of the total threshing area in the range from 3.5 to $4.1 \mathrm{~km} \mathrm{~h}^{-1}$. The average threshing rate of winter wheat was $3.7 \mathrm{~km} \mathrm{~h}^{-1}$ with average grain moisture of $14.4 \%$ and a yield of $8.1 \mathrm{t} \mathrm{ha}^{-1}$. Feiffer et al. [33] found that a more even crop of winter wheat resulted in a higher threshing rate of $9-33 \%$.

Grain moisture was also uniform and accounted for $75 \%$ of the total area in the range of $13.8-14.9 \%$ moisture. More evenly dried grain can be threshed earlier, and more even threshing speed results in higher harvester's performance.

The highest yield of winter wheat $9.2 \mathrm{tha}^{-1}$ was obtained by performing two additional fertilizations at growth stages $\mathrm{BBCH} 30$ and $\mathrm{BBCH} 37$ in the places where the lowest amount of $\mathrm{N}$ fertilizer was applied at a variable rate of $139 \mathrm{~kg} \mathrm{ha}^{-1}$.

\subsection{Fertilizer Use and Savings}

The results of comparison of VRF based on field soil analysis and crop nutrient demand with FRF, which takes into account only crop nutrient removal with the assumed 
average yield (Table 3). The results showed that less fertilizers were consumed when using the VRF method in 4-years compared to FRF: N $24 \mathrm{~kg} \mathrm{ha}^{-1}(4.6 \%), \mathrm{P}_{2} \mathrm{O}_{5} 124 \mathrm{~kg} \mathrm{ha}^{-1}$ $(48.6 \%), \mathrm{K}_{2} \mathrm{O} 93.1 \mathrm{~kg} \mathrm{ha}^{-1}(47.5 \%)$, respectively. The amounts of P element in the soil before the start of the experimental studies were higher (on an average three times in the whole field) than the recommended optimal amount. Therefore, in the phosphorus fertilization maps for variable fertilization, the rate of phosphorus fertilizers was reduced. A fixed rate of phosphorus fertilization was determined at the traditional recommended rate for each crop as shown in Table 3. These reasons resulted in more phosphorus savings than other fertilizers $\left(\mathrm{N}\right.$ and $\mathrm{K}_{2} \mathrm{O}$ ). Other researches stated that applying VRF of phosphorus fertilizer during the study period decreased the variability of the amount of this element in the soil [26]. The second-highest savings were achieved using potassium fertilizers, and average $\mathrm{K}_{2} \mathrm{O}$ level stayed at the optimum level at the end of the study. However, it needs to be clarified that the smallest $\mathrm{N}$ savings were achieved because variable $\mathrm{N}$ application software was created not for all crops. In our study, $\mathrm{N}$ application software was used only for winter wheat and oilseed rape. This could be the main reason why so little savings was found in $\mathrm{N}$-fertilizer during the 4 -year crop rotation. Other research have recorded 4 to $37 \%$ of nitrogen fertilizer savings in wheat in Turkey [4]. Yara International Research Centre (Hanninghof, Germany) applied tested winter wheat fertilization with $\mathrm{N}$ fertilizer at a variable rate with Yara N-Sensor in 2001-2005. Their test resulted in 12\% lower fertilizer consumption compared to uniform fertilization [34]. Koch et al. [35] found that variable rates of maize fertilization can save from 6 to $46 \%$ of the fertilizer compared to a uniform rate. Other researchers compared urea fertilization between FRF $\left(105 \mathrm{~kg} \mathrm{ha}^{-1}\right)$ and VRF $\left(64 \mathrm{~kg} \mathrm{ha}^{-1}\right)$ in maize production. According to Greenseeker's recommendation, they obtained an average yield of $3.9 \mathrm{t} \mathrm{ha}^{-1}$ in both fertilization methods [36].

Table 3. Fertilization rates and fertilizer reduction indicators.

\begin{tabular}{|c|c|c|c|c|c|c|c|c|}
\hline \multirow[b]{2}{*}{ Year } & \multirow[b]{2}{*}{ Crop } & \multirow{2}{*}{$\begin{array}{l}\text { Predicted } \\
\text { Yield } \\
\left(\mathrm{t} \mathrm{ha} \mathbf{a}^{-1}\right)\end{array}$} & \multirow[b]{2}{*}{ Fertilizer } & \multirow[b]{2}{*}{$\begin{array}{c}\text { Removal of } \\
\text { Fertilizer with } \\
\text { Yield (kg ha-1) }\end{array}$} & \multicolumn{4}{|c|}{ Fertilization Rate $\left(\mathrm{kg} \mathrm{ha}^{-1}\right)$} \\
\hline & & & & & VRF & FRF & $\begin{array}{l}\text { Difference } \\
\text { between FRF } \\
\text { and VRF }\end{array}$ & $\begin{array}{l}\text { Reduction } \\
\text { per } 1.0 \mathrm{t} \text { of } \\
\quad \text { Yield }\end{array}$ \\
\hline \multirow{3}{*}{2016} & \multirow{3}{*}{ Spring barley } & \multirow{3}{*}{7.0} & $\mathrm{~N}$ & 122.5 & 50.0 & 50.0 & 0.0 & 0.0 \\
\hline & & & $\mathrm{P}_{2} \mathrm{O}_{5}$ & 56.0 & 33.0 & 56.0 & 23.0 & 3.3 \\
\hline & & & $\mathrm{K}_{2} \mathrm{O}$ & 42.0 & 25.7 & 42.0 & 16.3 & 2.3 \\
\hline \multirow{4}{*}{2017} & \multirow{4}{*}{$\begin{array}{c}\text { Winter } \\
\text { oilseed rape }\end{array}$} & \multirow{4}{*}{5.0} & $\mathrm{~N}$ & 250.0 & 175.0 & 188.0 & 13.0 & 2.6 \\
\hline & & & $\mathrm{P}_{2} \mathrm{O}_{5}$ & 89.3 & 33.0 & 89.3 & 56.3 & 11.3 \\
\hline & & & $\mathrm{K}_{2} \mathrm{O}$ & 49.8 & 25.7 & 49.8 & 24.1 & 4.8 \\
\hline & & & $\mathrm{N}$ & 184.0 & 199.0 & 210.0 & 11.0 & 1.4 \\
\hline \multirow{3}{*}{2018} & \multirow{3}{*}{ Winter wheat } & \multirow{2}{*}{8.0} & $\mathrm{P}_{2} \mathrm{O}_{5}$ & 64.0 & 33.0 & 64.0 & 31.0 & 3.9 \\
\hline & & & $\mathrm{K}_{2} \mathrm{O}$ & 48.0 & 25.7 & 48.0 & 22.3 & 2.8 \\
\hline & & \multirow{3}{*}{4.0} & $\mathrm{~N}$ & 240.0 & 70.2 & 70.2 & 0.0 & 0.0 \\
\hline \multirow[t]{2}{*}{2019} & \multirow[t]{2}{*}{ Faba Bean } & & $\mathrm{P}_{2} \mathrm{O}_{5}$ & 47.6 & 33.0 & 47.6 & 14.6 & 3.6 \\
\hline & & & $\mathrm{K}_{2} \mathrm{O}$ & 56.0 & 25.7 & 56.0 & 30.3 & 7.6 \\
\hline \multirow{3}{*}{\multicolumn{2}{|c|}{ Total all years }} & & $\mathrm{N}$ & 819.5 & 494.2 & 518.2 & 24.0 & - \\
\hline & & & $\mathrm{P}_{2} \mathrm{O}_{5}$ & 256.9 & 132.1 & 256.9 & 124.8 & - \\
\hline & & & $\mathrm{K}_{2} \mathrm{O}$ & 195.8 & 102.7 & 195.8 & 93.1 & - \\
\hline & Total field & & & & 729.0 & 970.9 & 241.9 & \\
\hline
\end{tabular}

Notes: VRF-variable rate fertilization; FRF-fixed-rate fertilization.

Our research found that the total amount of saved NPK fertilizers was $241.6 \mathrm{~kg} \mathrm{ha}^{-1}$. In 4-years, from the total field were saved: $1418.8 \mathrm{~kg}$ of $\mathrm{P}_{2} \mathrm{O}_{5}, 1058.3 \mathrm{~kg}$ of $\mathrm{K}_{2} \mathrm{O}, 272.9 \mathrm{~kg}$ of N. Depending on the crop type, NPK fertilizer savings were uneven. The highest NPK fertilizer savings were in winter oilseed rape- $1061.8 \mathrm{~kg}(28.6 \%)$, spring barley- $446.7 \mathrm{~kg}$ $(40.1 \%)$, winter wheat $-731.0 \mathrm{~kg}(20.0 \%)$, and faba beans-510.4 $\mathrm{kg}(43.3 \%)$. The research showed that while maintaining the optimal average nutrient content in the field, less fertilizer was used to grow different crops. 


\subsection{Energy Use Reduction with VRF}

Compared VRF with FRF in spring barley (2016), energy consumption related to $\mathrm{P}_{2} \mathrm{O}_{5}$ and $\mathrm{K}_{2} \mathrm{O}$ fertilizers was lower at $41.0 \%$ and $38.9 \%$, respectively (Table 4 ). $\mathrm{N}$ variable fertilization was not applied for spring barley.

Table 4. Comparative energy consumption and reduction indicators using VRF and FRF.

\begin{tabular}{|c|c|c|c|c|c|c|c|c|c|}
\hline \multirow[b]{2}{*}{ Year } & \multirow[b]{2}{*}{ Crop } & \multirow{2}{*}{$\begin{array}{l}\text { Predicted } \\
\text { Yield } \\
\left(t \text { ha }^{-1}\right)\end{array}$} & \multirow[b]{2}{*}{ Fertilizer } & \multirow{2}{*}{$\begin{array}{c}\text { Energy } \\
\text { Equivalent } \\
\left(\mathbf{M J ~ k g}^{-1}\right)\end{array}$} & \multicolumn{4}{|c|}{ Energy Input (MJ ha $\left.{ }^{-1}\right)$} & \multirow{2}{*}{$\begin{array}{c}\text { Energy } \\
\text { Reduction MJ } \\
\text { per Total Field } \\
\text { Area (MJ } \\
\text { Field }^{-1} \text { ) } \\
\end{array}$} \\
\hline & & & & & VRF & FRF & $\begin{array}{c}\text { Difference } \\
\text { between FRF } \\
\text { and VRF }\end{array}$ & $\begin{array}{c}\text { Reduction } \\
\text { per } 1.0 \mathrm{t} \text { of } \\
\text { Yield }\end{array}$ & \\
\hline \multirow{3}{*}{2016} & \multirow{3}{*}{ Spring barley } & \multirow{3}{*}{7.0} & $\mathrm{~N}$ & 60.6 & 3030 & 3030 & 0.0 & 0.0 & 0.0 \\
\hline & & & $\mathrm{P}_{2} \mathrm{O}_{5}$ & 11.1 & 366.6 & 621.6 & 255.0 & 36.4 & 2899 \\
\hline & & & $\mathrm{K}_{2} \mathrm{O}$ & 6.7 & 172.1 & 281.4 & 109.3 & 15.6 & 1243 \\
\hline \multirow{4}{*}{2017} & \multirow{4}{*}{$\begin{array}{l}\text { Winter } \\
\text { oilseed rape }\end{array}$} & \multirow{4}{*}{5.0} & $\mathrm{~N}$ & 60.6 & 10605 & 11393 & 787.8 & 157.6 & 8957 \\
\hline & & & $\mathrm{P}_{2} \mathrm{O}_{5}$ & 11.1 & 366.6 & 991.2 & 624.6 & 124.9 & 7102 \\
\hline & & & $\mathrm{K}_{2} \mathrm{O}$ & 6.7 & 172.1 & 333.7 & 161.6 & 32.3 & 1837 \\
\hline & & & $\mathrm{N}$ & 60.6 & 12059 & 12726 & 666.6 & 83.3 & 7579 \\
\hline \multirow{3}{*}{2018} & \multirow{3}{*}{ Winter wheat } & \multirow[t]{3}{*}{8.0} & $\mathrm{P}_{2} \mathrm{O}_{5}$ & 11.1 & 366.6 & 710.4 & 343.8 & 43.0 & 3909 \\
\hline & & & $\mathrm{K}_{2} \mathrm{O}$ & 6.7 & 172.1 & 321.6 & 149.5 & 18.7 & 1700 \\
\hline & & & $\mathrm{N}$ & 60.6 & 4254 & 4254 & 0.0 & 0.0 & 0.0 \\
\hline \multirow[t]{2}{*}{2019} & \multirow[t]{2}{*}{ Faba bean } & \multirow[t]{2}{*}{4.0} & $\mathrm{P}_{2} \mathrm{O}_{5}$ & 11.1 & 366.6 & 528.4 & 161.7 & 40.4 & 1839 \\
\hline & & & $\mathrm{K}_{2} \mathrm{O}$ & 6.7 & 172.1 & 375.2 & 203.1 & 50.8 & 2310 \\
\hline \multirow{3}{*}{\multicolumn{2}{|c|}{ Total all years }} & & $\mathrm{N}$ & 60.6 & 29,949 & 31,403 & 1454 & - & 16,537 \\
\hline & & & $\mathrm{P}_{2} \mathrm{O}_{5}$ & 11.1 & 1467 & 2852 & 1385 & - & 15,748 \\
\hline & & & $\mathrm{K}_{2} \mathrm{O}$ & 6.7 & 688.2 & 1312 & 623.6 & - & 7091 \\
\hline \multicolumn{3}{|c|}{ Total field } & & & 32,103 & 35,566 & 3463 & - & 39,375 \\
\hline
\end{tabular}

Notes: VRF-variable rate fertilization; FRF-fixed-rate fertilization; total field area-11.37 ha.

In 2017 for winter oilseed rape applying VRF, energy consumption related to fertilizer $\mathrm{P}_{2} \mathrm{O}_{5}$ was lower $63.0 \%, \mathrm{~K}_{2} \mathrm{O}-48.4 \%$ and $\mathrm{N}-6.9 \%$, compared to FRF.

In 2018 for winter wheat using VRF, energy consumption related to $\mathrm{P}_{2} \mathrm{O}_{5}$ fertilizers was lower $48.4 \%, \mathrm{~K}_{2} \mathrm{O}-46.5 \%$ and $\mathrm{N}-5.2 \%$, compared to FRF practice.

In 2019 for faba beans applying VRF, energy consumption related to $\mathrm{P}_{2} \mathrm{O}_{5}$ fertilizers was lower $30.6 \%, \mathrm{~K}_{2} \mathrm{O}-54.1 \%$, compared to FRF method. $\mathrm{N}$ variable fertilization was not applied for faba beans.

Comparing VRF with FRF, the lowest energy savings were obtained by fertilizing winter wheat with $\mathrm{N}$ fertilizers, the highest-faba beans with $\mathrm{K}_{2} \mathrm{O}$.

Summarizing the crop rotation in 4-years, when the VRF fertilization method was applied, energy consumption for phosphorus fertilizers was $48.6 \%$ lower and for potassium fertilizers- $47.5 \%$ lower compared to the FRF fertilization method. Energy consumption related to nitrogen fertilizers was $4.6 \%$ lower compared to FRF. With variable fertilization, the total energy consumption for all fertilizers was $9.7 \%$ lower compared to FRF. The results showed that energy savings by reducing the application of $\mathrm{P}$ and $\mathrm{K}$ were generally lower compared to $\mathrm{N}$ fertilizer with respect to the energy use per ha due to fertilizer application. Summarizing the study's data on the energy consumption associated with NPK fertilizers over 4-years in the entire experimental field, it was found that the energy consumption of VRF was reduced by $9.7 \%$ Field $^{-1}$ compared to the FRF method.

\subsection{Changes in Fertilization Reduce Environmental Pollution}

By applying VRF according to a pre-arranged fertilization plan and using fertilizer application maps and efficient distribution equipment, we can reduce both fertilizer costs as well as GHG emissions. Comparison of a 4-year VRF with FRF method allowed concluding that lower GHG emissions were obtained due to the use of fertilizers: $119.0 \mathrm{~kg} \mathrm{CO}$ eq $\mathrm{ha}^{-1}$ of $\mathrm{N}, 168.5 \mathrm{~kg} \mathrm{CO}_{2 \text { eq }}$ ha $^{-1}-\mathrm{P}_{2} \mathrm{O}_{5}, 54.0 \mathrm{~kg} \mathrm{CO}$ eq ha $^{-1}-\mathrm{K}_{2} \mathrm{O}$, respectively (Table 5). Similar research in Latvia showed that a variable $\mathrm{N}$ fertilizer application in winter wheat reduced GHG emissions by $46.8 \mathrm{~kg} \mathrm{CO}_{2 \mathrm{eq}}$ ha $^{-1}$ or $6 \%$ compared to a fixed rate $\mathrm{N}$ fertilizer application technology [37]. 
Table 5. Reduction of GHG emissions by using variable and fixed rates of fertilization.

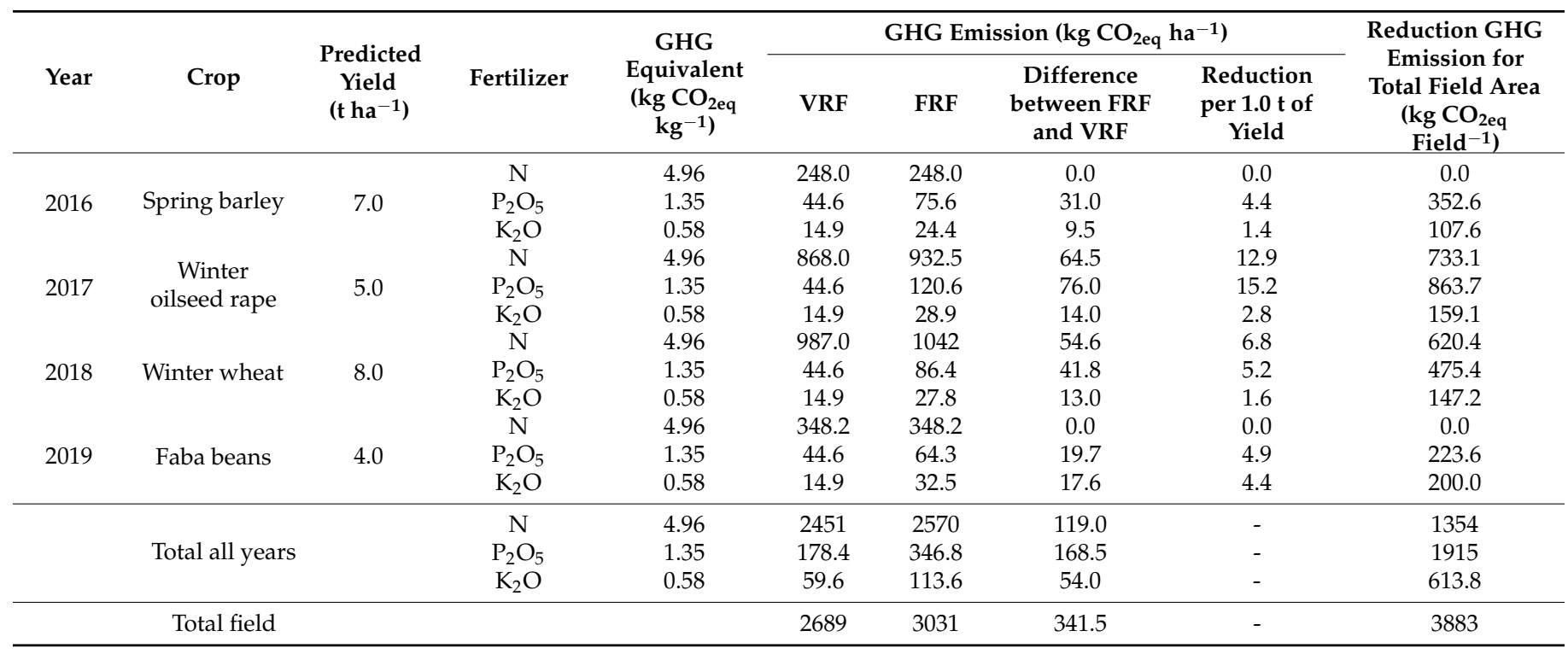

Notes: VRF-variable rate fertilization; FRF-fixed-rate fertilization; total field area-11.37 ha.

Our study found an overall reduction in GHG emissions of $341.5 \mathrm{~kg} \mathrm{CO}_{2 \mathrm{eq}} \mathrm{ha}^{-1}$. Most greenhouse gas emissions reductions using the VRF method were achieved with $\mathrm{P}_{2} \mathrm{O}_{5}$ $\left(168.5 \mathrm{~kg} \mathrm{CO}_{2 \mathrm{eq}} \mathrm{ha}^{-1}\right)$. Fertilization with NPK fertilizers in the whole field at a variable rate over 4-years reduced the GHG emissions by $3882.6 \mathrm{~kg} \mathrm{CO}_{2 \mathrm{eq}}(11.27 \%)$. This study shows that GHG emissions in the experimental field decreased over 4-years, depending on the type of fertilizer: $48.6 \%$ for $\mathrm{P}_{2} \mathrm{O}_{5}, 47.5 \%-\mathrm{K}_{2} \mathrm{O}$ and $4.6 \%-\mathrm{N}$, respectively. Balafoutis et al. [16] reported that the use of VRF technology can reduce the GHG emission potential of $5 \%$ attributed to the use of $\mathrm{N}$ mineral fertilizers without yield effects. Italy scientist's findings suggest that VRF is able to decrease $\mathrm{CO}_{2}$ emission in comparison with FRF [38].

According to the crop rotation, different GHG emissions were obtained by growing different crops and applying VRF, compared to FRF method in the whole study field: $460.2 \mathrm{~kg} \mathrm{CO}_{2 \mathrm{eq}}$ Field $^{-1}$ for spring barley, $1755.9 \mathrm{~kg} \mathrm{CO}_{2 \mathrm{eq}}$ Field $^{-1}$-winter rape, $1242.9 \mathrm{~kg}$ $\mathrm{CO}_{2 \mathrm{eq}}$ Field $^{-1}$-winter wheat, $423.6 \mathrm{~kg} \mathrm{CO}_{2 \mathrm{eq}}$ Field $^{-1}$-faba beans, respectively. The study showed that the greatest savings in GHG emissions were achieved in winter oilseed rape.

\subsection{Economic Benefits}

An evaluation of the economic benefits of changing a fixed fertilization rate to a variable rate in order to save the cost for fertilizers for the entire research field over 4 years was performed. It was revealed that when the price of $\mathrm{N}$ was $0.9 € \mathrm{~kg}^{-1}$ and the amount of fertilizer used was $272.9 \mathrm{~kg}$, the economic benefit was achieved $21.6 € \mathrm{ha}^{-1}$. When the price of the fertilizer $\mathrm{P}_{2} \mathrm{O}_{5}$ was $0.8 € \mathrm{~kg}^{-1}$ and $\mathrm{K}_{2} \mathrm{O} 0.5 € \mathrm{~kg}^{-1}$ and their consumption was 1418.8 and $1058.3 \mathrm{~kg}$, then the savings were 99.8 and $46.5 € \mathrm{ha}^{-1}$, respectively. The total 4-year economic benefit for the whole field due to the savings on NPK fertilizers was $168.0 € \mathrm{ha}^{-1}$. Other researchers [34], who compared fertilization at a fixed rate with the one at a variable rate, calculated an economic benefit of $19 \$(\sim 16.4 €)$ per hectare from savings on nitrogen fertilizers. Diacono et al. [3] analyzed the cost-effectiveness of variable rate $\mathrm{N}$ fertilizer management methods in wheat crops and concluded that real-time N-based management had the higher profitability, ranging from 5 to $60 \$ \mathrm{ha}^{-1}\left(\sim 4.3\right.$ to $\left.\sim 51 € \mathrm{ha}^{-1}\right)$ compared to FRF. Dobermann et al. [39] found that fertilization of rice with NPK fertilizers using VRF can increase the yields by $12 \%$ compared to FRF.

A comparative analysis of the yields showed that VRF had an advantage over FRF due to higher crop yields. In our studies, no actual yield results were obtained using fixed rate fertilization. Yields for all four plants were assumed on the basis of average values from previous years. Using the VRF system, the yields of different crops obtained were 
very similar to the assumed yields used for the FRF method. Other authors also found that the average wheat grain yield was $4.24 \mathrm{t} \mathrm{ha}^{-1}$ and the mean increase in wheat grain yield applying VRF was $0.8 \%$ when compared with the FRF treatment averaged over 10 sites and two years [40]. In the study of scientists from Italy, there were no significant differences of the barley grain yield between FRF and VRF technologies observed [38]. The method used to apply variable $\mathrm{N}$ fertilization has been proved to be effective, leading to a similar barley yield to conventional practice while using less fertilizer $\left(75 \mathrm{~kg} \mathrm{~N} \mathrm{ha}^{-1}\right)$. The VRF method has been proved to be a valid alternative to conventional fertilization, considering economic evaluation and leading a saving of $266 € \mathrm{ha}^{-1}$ [38].

All crops yielded economic benefits, except for faba beans. A 4-year benefit due to the increased yield was $108.0 € \mathrm{ha}^{-1}$. Comparing VRF and FRF methods of spring barley, winter oilseed rape, winter wheat and faba beans, the economic benefits from the yield were $45,70,17$ and $-24 € \mathrm{ha}^{-1}$, respectively. Economic benefit from yield was calculated using the grain price for each crop: $150 € \mathrm{ha}^{-1}$ for spring barley, $350 € \mathrm{ha}^{-1}$-winter oilseed rape, $170 € \mathrm{ha}^{-1}$-winter wheat and $240 € \mathrm{ha}^{-1}$-faba beans, respectively.

The greatest savings of energy input and GHG emissions were obtained with $\mathrm{N}$ and $\mathrm{P}_{2} \mathrm{O}_{5}$ fertilizers at a variable rate in winter oilseed rape. Comparing different fertilizers, the best cost savings results were achieved using $\mathrm{P}_{2} \mathrm{O}_{5}$ fertilizers for winter oilseed rape, winter wheat, and spring barley 45, 24.8, and 18.4, respectively. For all fertilizers, energy inputs, GHG emissions, and cost savings using VRF comparing to FRF are presented in Figure 11.

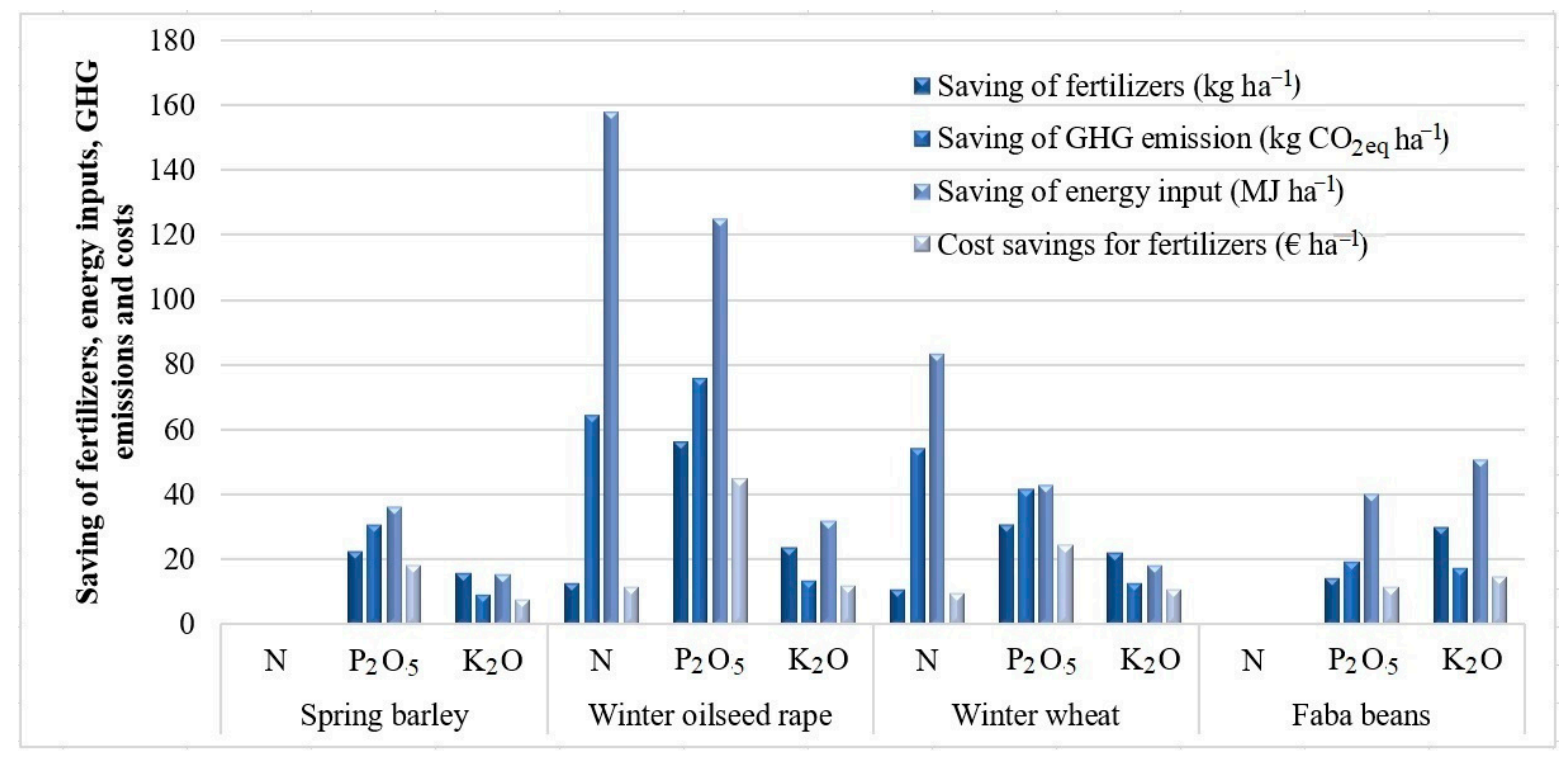

Figure 11. Fertilizers, energy inputs, GHG emissions and cost savings using VRF comparing to FRF.

Summarizing the research results obtained in this study, it can be stated that variable fertilization is an important technological process that reduces the consumption and the costs of NPK fertilizers, saves energy costs, and contributes to the preservation of a cleaner environment. In order to achieve even stronger positive energy, as well as economic and environmental impact, future research needs to investigate the technological processes of not only fertilization but also of sowing and spraying of plant protection products at a variable rate.

\section{Conclusions}

A 4-year study of soil elements showed that even after 4-years of using VRF, excess phosphorus of $48.5 \mathrm{mg}$ per $100 \mathrm{~g}$ of soil and potassium with $27.6 \mathrm{mg}$ per $100 \mathrm{~g}$ of soil were still present in certain field areas. Repeated soil element analysis showed that application of VRF, taking into account the existing nutrient content in the soil and demand of elements 
for the crop, can save fertilizers and reduce environmental impact without over-fertilizing $\mathrm{P}_{2} \mathrm{O}_{5}$ and $\mathrm{N}$ in the areas where there was already an excess of these elements. In the experimental field, the application of VRF maps allowed avoiding over-fertilization in separate field locations, thus saving fertilizers and making the obtained yield closer to the planned one. Application of this method allowed reducing the costs of fertilizers: $4.6 \%$ for $\mathrm{N}, 48.6 \%-\mathrm{P}_{2} \mathrm{O}_{5}$ and $47.5 \%-\mathrm{K}_{2} \mathrm{O}$. The total consumption of NPK fertilizers was lower by $24.9 \%$ compared to the FRF. Thus, variable rate fertilization results in higher fertilizer use efficiency.

Lower consumption of mineral fertilizers resulted in lower energy consumption throughout the 4-year crop rotation. With VRF, the total energy input for all fertilizers was $3463.1 \mathrm{MJ} \mathrm{ha}^{-1}$ or $9.74 \%$ lower than with FRF. The largest reduction in energy consumption was found for nitrogen and phosphorus fertilizers, 1454.4 and $1385.1 \mathrm{MJ} \mathrm{ha}^{-1}$, respectively. Lower spreads of fertilizers all over the field resulted in lower GHG emissions to the environment during the study period. Phosphorus and potassium VRF application was estimated to reduce the GHG emissions by almost twice compared to FRF. For the total amount of NPK fertilizers, 11.3\% lower GHG emissions were obtained. At the end of the study, GHG emission reductions of $341.5 \mathrm{~kg} \mathrm{CO}_{2 \mathrm{eq}}$ ha ${ }^{-1}$ or $3882.6 \mathrm{~kg} \mathrm{CO}_{2 \mathrm{eq}}$ Field $^{-1}$ were determined.

VRF, according to the application plan and by using VRF maps, allowed a reduction in NPK fertilizers by $241.9 \mathrm{~kg} \mathrm{ha}^{-1}$ or $2750.0 \mathrm{~kg}^{\text {Field }}{ }^{-1}$. A significant decrease in the need of mineral fertilizers reduced production costs and contributed to cleaner agricultural production. The total economic benefit coming from the saved funds for fertilizers due to an application of VRF was $168.0 € \mathrm{ha}^{-1}$ or $1909.7 €$ Field $^{-1}$.

Based on the results of our study, we can say that the application of the VRF method allows farmers to benefit from lower costs for fertilizers and, at the same time, helps them to meet the EU's requirements for environmental pollution in agriculture. The energy, economic, and environmental benefits of variable rate fertilization are a great recommendation to continue this type of research in the future, including more details on precision farming such as variable rate sowing, spraying of growth regulators, and plant protection products.

Author Contributions: Conceptualization, M.K. and E.Š.; methodology, M.K., I.B., and E.Š.; validation, M.K. and A.J.; formal analysis, A.J. and I.B.; investigation, M.K. and I.B.; resources, E.Š., A.J. and M.K.; data curation, M.K. and I.B.; writing-original draft preparation, M.K., I.B., A.J., and E.Š.; writing-review and editing, E.Š. and A.J.; visualization, M.K. and I.B.; supervision, E.Š. All authors have read and agreed to the published version of the manuscript.

Funding: This research received no external funding.

Data Availability Statement: The data presented in this study are available on request from the corresponding author.

Conflicts of Interest: The authors declare no conflict of interest.

\section{References}

1. Savci, S. An agricultural pollutant: Chemical fertilizer. Int. J. Environ. Sci. Dev. 2012, 3, 77-80. [CrossRef]

2. Food and Agriculture Organization of the United Nations. World Food and Agriculture-Statistical Yearbook 2020; Food and Agriculture Organization of the United Nations: Rome, Italy, 2020; Available online: https:/ / doi.org/10.4060/cb1329en (accessed on 20 October 2020).

3. Diacono, M.; Rubino, P.; Montemurro, F. Precision nitrogen management of wheat. Agron. Sustain. Dev. 2013, 33, 219-241. [CrossRef]

4. Tekin, A.B. Variable rate fertilizer application in Turkish wheat agriculture: Economic assessment. Afr. J. Agric. Res. 2010, 5, 647-652.

5. Shi, Y.; Zhu, Y.; Wang, X.; Sun, X.; Ding, Y.; Cao, W.; Hu, Z. Progress and development on biological information of crop phenotype research applied to real-time variable-rate fertilization. Plant Methods 2020, 16, 11. [CrossRef]

6. Miller, N.J.; Griffin, T.W.; Ciampitti, I.A.; Sharda, A. Farm adoption of embodied knowledge and information intensive precision agriculture technology bundles. Precis. Agric. 2019, 20, 348-361. [CrossRef] 
7. Roberts, T.L. Right product, right rate, right time, and right place ... the foundation of best management practices for fertilizer. In Fertilizer Best Management Practices, 1st ed.; Papers Presented at the IFA International Workshop on Fertilizer Best Management Practices, Brussels, Belgium, 7-9 March 2007; International Fertilizer Industry Association: Paris, France, 2007 ; pp. $29-32$.

8. Fixen, P.E. Can we define a global framework within which fertilizer best management practices can be adapted to local conditions? In Fertilizer Best Management Practices, 1st ed.; Papers presented at the IFA International Workshop on Fertilizer Best Management Practices, Brussels, Belgium, 7-9 March 2007; International Fertilizer Industry Association: Paris, France, 2007; pp. 77-86.

9. Hunt, E.R., Jr.; Daughtry, C.S. What good are unmanned aircraft systems for agricultural remote sensing and precision agriculture? Int. J. Remote Sens. 2018, 39, 5345-5376. [CrossRef]

10. Schumann, A.W. Precise placement and variable rate fertilizer application technologies for horticultural crops. Horttechnology 2010, 20, 34-40. [CrossRef]

11. Grisso, R.D.; Alley, M.M.; Thomason, W.E.; Holshouser, D.L.; Roberson, G.T. Precision farming tools: Variable-rate application. Extension 2011, 442-505, 1-16.

12. Bogue, R. Sensors key to advances in precision agriculture. Sens. Rev. 2017, 37, 1-6. [CrossRef]

13. Khanal, S.; Fulton, J.; Shearer, S. An overview of current and potential applications of thermal remote sensing in precision agriculture. Comput. Electron. Agric. 2017, 139, 22-32. [CrossRef]

14. Frasconi, C.; Raffaelli, M.; Emmi, L.; Fontanelli, M.; Martelloni, L.; Peruzzi, A. An automatic machine able to perform variable rate application of flame weeding: Design and assembly. Chem. Eng. Trans. 2017, 58, 301-306.

15. Montzka, S.A.; Dlugokencky, E.J.; Butler, J.H. Non-CO 2 greenhouse gases and climate change. Nature 2011, 476, 43-50. [CrossRef] [PubMed]

16. Balafoutis, A.; Beck, B.; Fountas, S.; Vangeyte, J.; Wal, T.V.D.; Soto, I.; Gomez-Barbero, M.; Barnes, A.; Eory, V. Precision agriculture technologies positively contributing to GHG emissions mitigation, farm productivity and economics. Sustainability 2017, 9, 1339. [CrossRef]

17. Millar, N.; Robertson, G.P.; Grace, P.R.; Gehl, R.J.; Hoben, J.P. Nitrogen fertiliser management for nitrous oxide (N2O) mitigation in intensive corn (Maize) production: An emissions reduction protocol for US Midwest agriculture. Mitig. Adapt. Strat. Glob. Chang. 2010, 15, 185-204. [CrossRef]

18. Brown, T.T. Variable Rate Nitrogen and Seeding to Improve Nitrogen Use Efficiency. Ph.D. Dissertation, Washington State University, Washington, DC, USA, 2015; pp. 1-205.

19. Basso, B.; Fiorentino, C.; Cammarano, D.; Schulthess, U. Variable rate nitrogen fertilizer response in wheat using remote sensing. Precis. Agric. 2016, 17, 168-182. [CrossRef]

20. Rogovska, N.; Laird, D.A.; Chiou, C.P.; Bond, L.J. Development of field mobile soil nitrate sensor technology to facilitate precision fertilizer management. Precis. Agric. 2019, 20, 40-55. [CrossRef]

21. Nawar, S.; Corstanje, R.; Halcro, G.; Mulla, D.; Mouazen, A.M. Delineation of soil management zones for variable-rate fertilization: A review. Adv. Agron. 2017, 143, 175-245.

22. Tremblay, N. Modelling and decision support systems in precision agriculture. In Book Precision Agriculture for Sustainability; Stafford, J., Ed.; Burleigh Dodds Science Publishing Limited: Cambridge, UK, 2019; Chapter 6; pp. 145-168.

23. Ferguson, R.B. Proximal crop sensing. In Book Precision Agriculture for Sustainability; Stafford, J., Ed.; Burleigh Dodds Science Publishing Limited: Cambridge, UK, 2019; Chapter 1; pp. 3-28.

24. Burton, L.; Jayachandran, K.; Bhansali, S. Review-The "real-time" revolution for in situ Soil nutrient sensing. J. Electrochem. Soc. 2020, 167, 037569. [CrossRef]

25. Saiz-Rubio, V.; Rovira-Más, F. From smart farming towards agriculture 5.0: A review on crop data management. Agronomy 2020, 10, 207. [CrossRef]

26. Kulczycki, G.; Grocholski, P. The effect of long-term phosphorus and potassium precision fertilization. In Precision Agriculture'13; Wageningen Academic Publishers: Wageningen, The Netherlands, 2013; pp. 395-401.

27. Von Wulffen, U.; Roschke, M.; Kape, H.E. Guide values for examination and advice as well as for the technical implementation of the Fertilizer Ordinance (DüV). Common information from the states of Brandenburg, Mecklenburg-Western Pomerania and Saxony-Anhalt; State Office for Consumer Protection: Frankfurt/Oder, Germany, 2008; pp. 1-84.

28. Friedrich, J.; Klingner, S.; Becker, M.; Schneider, M. IPS-An Information Production System for Precision Farming. Landtechnik 2016, 71, 35-42.

29. Lal, B.; Gautam, P.; Nayak, A.K.; Panda, B.B.; Bihari, P.; Tripathi, R.; Shahid, M.; Guru, P.K.; Chatterjee, D.; Kumar, U.; et al. Energy and carbon budgeting of tillage for environmentally clean and resilient soil health of rice-maize cropping system. J. Clean. Prod. 2019, 226, 815-830. [CrossRef]

30. Lal, R. Carbon emission from farm operations. Environ. Int. 2004, 30, 981-990. [CrossRef] [PubMed]

31. Tukey, J.W. Methodology, and the statistician's responsibility for both accuracy and relevance. J. Am. Stat. Assoc. 1979, 74, 786-793. [CrossRef]

32. Tarakanovas, P.; Raudonius, S. Statistical Analysis of Agronomic Research Data Using Computer Programs Anova, Stat, Split-Plot from the Package Selection and Irristat: A Methodological Tool for Master's and Doctoral Students of the Faculty of Agronomy; Lithuanian Institute of Agriculture: Akademija, Lithuania, 2003. 
33. Feiffer, A.; Jasper, J.; Leithold, P.; Feiffer, P. Effects of N-Sensor based variable rate. N fertilization on combine harvest. Staff. J V. Precis. Agric. 2007, 7, 673-679.

34. Precision Farming for Sustainable Agriculture. Available online: https://www.yara.lt/globalassets/country-websites/campaignassets/nbs-campaign/sub-pages/profit-page/crop-performance/pure-nutrient-fact-3-precision-farming.pdf/ (accessed on 15 October 2020).

35. Koch, B.; Khosla, R.; Frasier, W.M.; Westfall, D.G.; Inman, D. Economic feasibility of variable-rate nitrogen application utilizing site-specific management zones. Agron. J. 2004, 96, 1572-1580. [CrossRef]

36. Robertson, M.; Carberry, P.; Brennan, L. The Economic Benefits of Precision Agriculture: Case Studies from Australian Grain Farms; CSIRO: Canberra, Australia, 2007; pp. 1-46.

37. Lenerts, A.; Berzins, G.; Popluga, D. Nitrogen fertilizer use efficiency and GHG emissions in the Latvian grain sector. In Proceedings of the Engineering for Rural Development, Jelgava, Latvia, 25-27 May 2016.

38. Fabbri, C.; Napoli, M.; Verdi, L.; Mancini, M.; Orlandini, S.; Dalla Marta, A. A Sustainability Assessment of the Greenseeker N Management Tool: A Lysimetric Experiment on Barley. Sustainability 2020, 12, 7303. [CrossRef]

39. Dobermann, A.; Witt, C.; Dawe, D. Performance of site-specific nutrient management in intensive rice cropping systems of Asia. Better Crops Int. 2002, 16, 25-30.

40. Mayfield, A.H.; Trengove, S.P. Grain yield and protein responses in wheat using the N-Sensor for variable rate N application. Crop Pasture Sci. 2009, 60, 818-823. [CrossRef] 